\title{
The role of polymorphism in various potential genes on polycystic ovary syndrome susceptibility and pathogenesis
}

\author{
Hiral Chaudhary', Jalpa Patel ${ }^{1}$, Nayan K. Jain² and Rushikesh Joshi ${ }^{1 *}$ (D)
}

\begin{abstract}
Polycystic ovary syndrome (PCOS) is the most common endocrinopathies affecting the early reproductive age in women, whose pathophysiology perplexes many researchers till today. This syndrome is classically categorized by hyperandrogenism and/or hyperandrogenemia, menstrual and ovulatory dysfunction, bulky multi follicular ovaries on Ultrasonography (USG), and metabolic abnormalities such as hyperinsulinemia, dyslipidemia, obesity. The etiopathogenesis of PCOS is not fully elucidated, but it seems that the hypothalamus-pituitary-ovarian axis, ovarian, and/ or adrenal androgen secretion may contribute to developing the syndrome. Infertility and poor reproductive health in women's lives are highly associated with elevated levels of androgens. Studies with ovarian theca cells taken from PCOS women have demonstrated increased androgen production due to augmented ovarian steroidogenesis attributed to mainly altered expression of critical enzymes (Cytochrome P450 enzymes: CYP17, CYP21, CYP19, CYP11A) in the steroid hormone biosynthesis pathway. Despite the heterogeneity of PCOS, candidate gene studies are the widely used technique to delineate the genetic variants and analyze for the correlation of androgen biosynthesis pathway and those affecting the secretion or action of insulin with PCOS etiology. Linkage and association studies have predicted the relationship between genetic variants and PCOS risk among families or populations. Several genes have been proposed as playing a role in the etiopathogenesis of PCOS, and the presence of mutations and/or polymorphisms has been discovered, which suggests that PCOS has a vital heritable component. The following review summarizes the influence of polymorphisms in crucial genes of the steroidogenesis pathway leading to intraovarian hyperandrogenism which can result in PCOS.
\end{abstract}

Keywords: Polycystic ovary syndrome, Hyperandrogenism, Ovarian steroidogenesis, Gonadotropins, Candidate genes, Polymorphism

\section{Introduction}

Polycystic ovary syndrome (PCOS) is the most common endocrinopathies, first reported in 1935 by Stein I. F and Leventhal M. L [1]. WHO's estimated ratio of PCOS affecting women of reproductive age group worldwide is 116 million (3.6\%) [2]. Globally, the prevalence of PCOS

\footnotetext{
*Correspondence: rushikeshjoshi@gujaratuniversity.ac.in; rushikesh1987@gmail.com

1 Department of Biochemistry and Forensic Science, University School of Sciences, Gujarat University, Ahmedabad, Gujarat 380009, India Full list of author information is available at the end of the article
}

is varying from $2.2 \%$ to as high as $26 \%$. Based on the 1990 US National Institutes of Health (NIH) diagnostic criteria, the prevalence rate from the United States, Europe, Asia, and Australia is between 5 to $9 \%$ and approximately between 4 to $21 \%$ when Rotterdam 2003 criteria is applied in clinically evident PCOS women of reproductive age [3]. In India, the prevalence estimate is $10 \%$ and yet no clear statistical data is available [4].

PCOS is majorly characterized by hyperandrogenism and/or hyperandrogenemia, menstrual and ovulatory dysfunction manifested as oligomenorrhea, amenorrhea

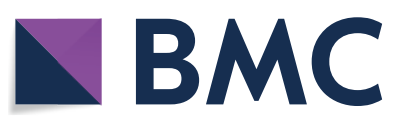

(c) The Author(s) 2021. Open Access This article is licensed under a Creative Commons Attribution 4.0 International License, which permits use, sharing, adaptation, distribution and reproduction in any medium or format, as long as you give appropriate credit to the original author(s) and the source, provide a link to the Creative Commons licence, and indicate if changes were made. The images or other third party material in this article are included in the article's Creative Commons licence, unless indicated otherwise in a credit line to the material. If material is not included in the article's Creative Commons licence and your intended use is not permitted by statutory regulation or exceeds the permitted use, you will need to obtain permission directly from the copyright holder. To view a copy of this licence, visit http://creativecommons.org/licenses/by/4.0/. The Creative Commons Public Domain Dedication waiver (http://creativeco mmons.org/publicdomain/zero/1.0/) applies to the data made available in this article, unless otherwise stated in a credit line to the data. 
or chronic anovulation, and polycystic ovarian morphology (PCOM: an excessive number of preantral follicles in ovaries) [5]. Clinical Hyperandrogenemia leads to excessive terminal hair growth on the face or body suggesting masculine features known as hirsutism and leads to cosmetic consequences such as acne and alopecia (male pattern baldness). In contrast, biochemical hyperandrogenism results in excessive production of androgens and insulin resistance [6]. It is also associated with metabolic risk factors including hyperinsulinemia, Type II Diabetes mellitus, hypertension, dyslipidemia, and cardiovascular disorders [7].

An alteration observed in the steroid biosynthesis pathway increases the androgen levels in PCOS women [8]. Most of the enzymes involved in the biosynthesis of the adrenal steroid hormones and the gonadal steroid hormones fall into two major classes of proteins: the cytochrome $\mathrm{P} 450$ heme-containing proteins and the hydroxysteroid dehydrogenases. The P450 enzymes involved in steroid hormone biosynthesis are membrane-bound proteins associated with the mitochondrial membranes CYP11A, CYP11B1, and CYP11B2, or the endoplasmic reticulum (microsomal) CYP17, CYP19, and CYP21. Studies have shown that hyperandrogenism, luteinizing hormone (LH) hypersecretion, hyperinsulinemia are majorly associated with the pathophysiology of PCOS [9]. Hyperandrogenism is prominently observed in the ovary of PCOS women, which leads to intense ovarian steroidogenesis [10]. For ages, ovarian function is affected by androgens which are often associated with infertility. Androgen excess is the main factor promoting anovulation and follicular arrest, suggesting decreased oocyte development and maturation [11]. Several genes have been proposed as playing a role in the etiopathogenesis of PCOS, and the presence of mutations and/or polymorphisms has been discovered. However, their exact role is still not clear [12]. The central genes explored in the steroidogenesis pathway and gonadotropin action and regulation in developing PCOS are explained in this review article.

\section{Etio-pathogenesis}

The term polycystic ovary syndrome was coined after Stein and Leventhal studied ovarian morphology and histology and numerous clinical findings that verified the existence of polycystic ovaries in women [13]. The National Institutes of Health (NIH) Conference suggested in 1990 when the diagnostic criteria for PCOS were first introduced that both hyperandrogenism and chronic anovulation be always present [14]. Later, in 2003, the ESRHE/ASRM Rotterdam criteria specified PCOS by requiring at least two of three characteristics of oligo-ovulation/anovulation, hyperandrogenism, and polycystic ovaries on USG to be present [15].. In 2006, the Androgen Excess Society (AES) proposed an amendment, in which oligo-ovulation/anovulation or polycystic ovaries on ultrasonography should accompany a clinical or biochemical diagnosis of hyperandrogenism [16].

PCOS being a multigenic trait, described in Fig. 1: Implications of Polycystic ovary syndrome in women's lives; many pathways may be involved in its etiology. Researchers are studying PCOS for ages and generated many hypotheses about the PCOS development and its characteristics features, but the etiology behind the syndrome is still unclear. The pathogenesis of PCOS is associated primarily with theca cell defects along with neuroendocrine dysfunction of the hypothalamic-pituitary-ovarian axis resulting in hyperandrogenism [17]. In normal conditions, the hypothalamus signals the pituitary gland to release Gonadotropin-releasing hormone $(\mathrm{GnRH})$, which further stimulates the normal signaling pathway for releasing Luteinizing hormone (LH) and Follicle-stimulating hormone (FSH). Studies have shown a significant increase in the frequency and the amplitude of LH release reflecting an increase in GnRH secretion with average/reduced FSH secretion, suggesting the presence of hypothalamic defects in PCOS $[18,19]$. The elevated LH/FSH ratio is commonly observed in ovulatory women with polycystic ovary morphology (PCOM) [20]. The excessive hypothalamic GnRH secretion in PCOS patients shows a reduced sensitivity to inhibition by estradiol and progesterone [17]. Studies have also shown the role of neuropeptide kisspeptin coded by Kiss 1 gene as GnRH pulse generator. The GnRH neurons get a direct signal by Kisspeptin, which acts upstream of $\mathrm{GnRH}$, to control pulsatile GnRH release [21]. Experimental studies in prenatally androgenized monkeys show the neuroendocrine dysregulation of the hypothalamicpituitary-ovarian axis, resulting in increasing production of luteinizing hormone followed by increased ovarian androgen production [22]. Although androgen excess is a primary abnormality in PCOS, independent from hypothalamic-pituitary neuroendocrine dysregulation, studies so far have reported the dysregulation in the feedback loops between the hypothalamus-pituitary and the ovary.

\section{Steroidogenesis and hyperandrogenism}

The ovary is the major site for steroidogenesis, where the differentiation of theca cells and granulosa cells plays a vital role in follicular development and maturation. In a normally ovulating woman, the theca interna of the ovarian follicle and the adrenal cortex's zona fasciculata significantly contribute to the secretion of androstenedione, and granulosa cells influence the conversion of androstenedione to estradiol under the activity of aromatase. Furthermore, the enzymes involved in the 


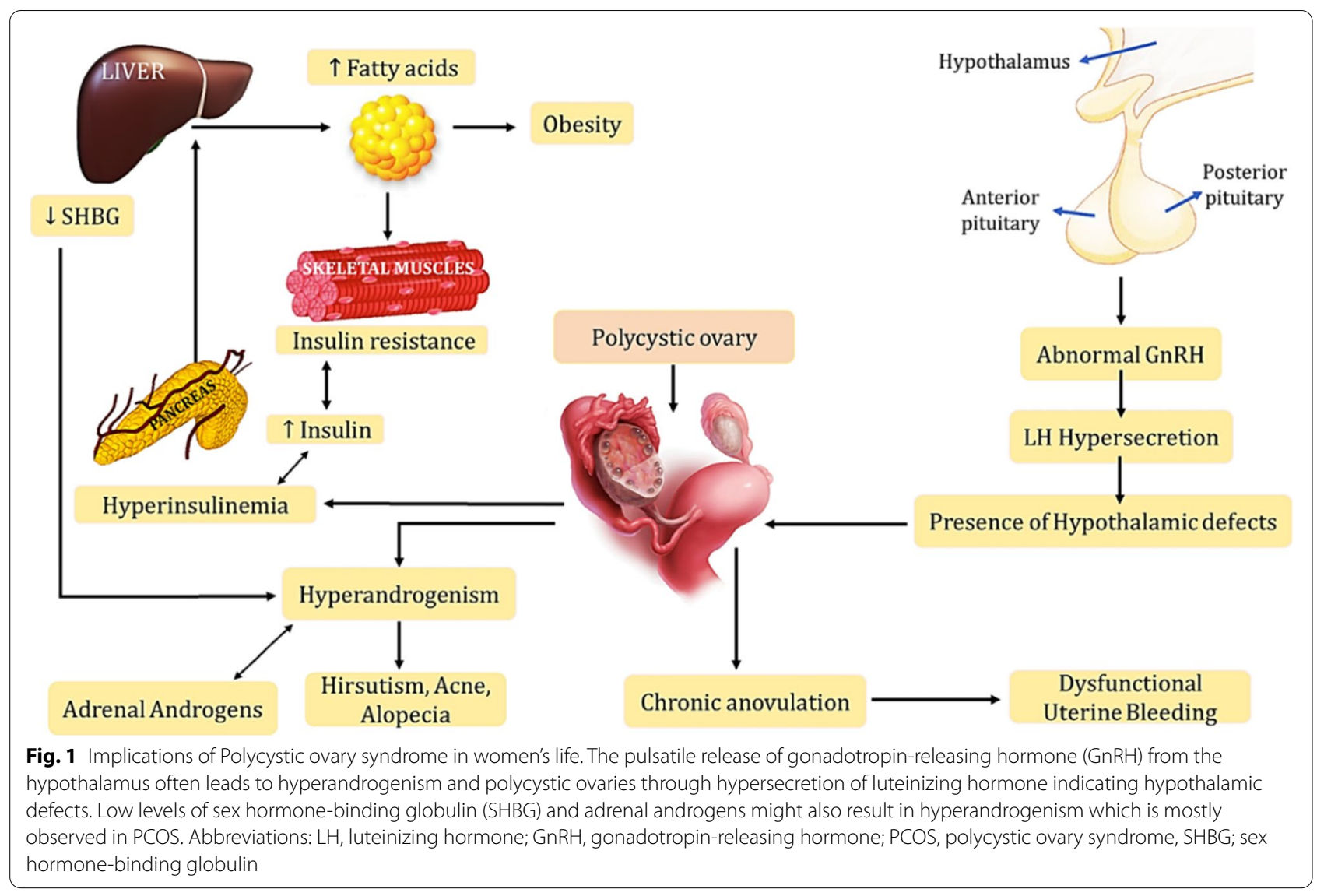

formation of androstenedione and estradiol are regulated by $\mathrm{LH}, \mathrm{FSH}$, and adrenocorticotrophic hormone $(\mathrm{ACTH})$ in the ovary and adrenal glands [23-25]. The conversion of precursor cholesterol to biologically active steroid hormones is known as steroidogenesis. Steroidogenic enzymes, which include several cytochrome P450 enzymes (CYP), hydroxysteroid dehydrogenases (HSDs), and steroid reductases, carry out the biosynthesis of various steroid hormones, like androgens and estrogens [26]. The pre-requisite step that forms the precursors for other steroid hormones is the conversion of cholesterol to pregnenolone by CYP11A (cholesterol side-chain cleavage) and pregnenolone to progesterone by 3-hydroxysteroid dehydrogenase (3-HSD) specified in Fig. 2: Schematic diagram of Steroidogenesis pathway and the enzymes involved in the biosynthesis [27]. Under the influence of high pulse LH release, theca cells increase steroidogenic activity and upregulate the StAR, P450scc, 3-HSD, and CYP17, which produces androstenedione, which is further enhanced by increased levels of insulin commonly observed in PCOS women [28]. Insulin resistance and hyperinsulinemia lower the levels of sex hormone-binding globulin (SHBG), leading to an increase in androgen production [29]. Under the influence of pituitary FSH, androstenedione is converted to estrogen by aromatase present in granulosa cells [28]. In PCOS women, hyperactive ovarian theca steroidogenesis causes the overproduction of androgenic steroids, mainly 7-hydroxyprogesterone and androstenedione resulting in hyperandrogenism [30]. Furthermore, PCOS women have reduced aromatase activity and follicular development is impaired and arrested due to the relative decrease in FSH secretion, resulting in excess androgen accumulation and hyperandrogenemia [30]. Therefore, hyperandrogenism seems to play a crucial role in the pathogenesis of PCOS, contributing to the reproductive and metabolic aspects of the syndrome.

\section{Candidate genes involved in pathophysiology of PCOS}

The increasing evidence of PCOS, hyperandrogenism, and metabolic alterations, and their hereditability is more observed in affected siblings of the family cluster than the general population [31-33]. There are several welldemonstrated biochemical abnormalities, despite the heterogeneity of PCOS, that can provide a reliable basis for adapting a candidate gene approach to the identification of susceptibility loci. So far, several genetic studies 


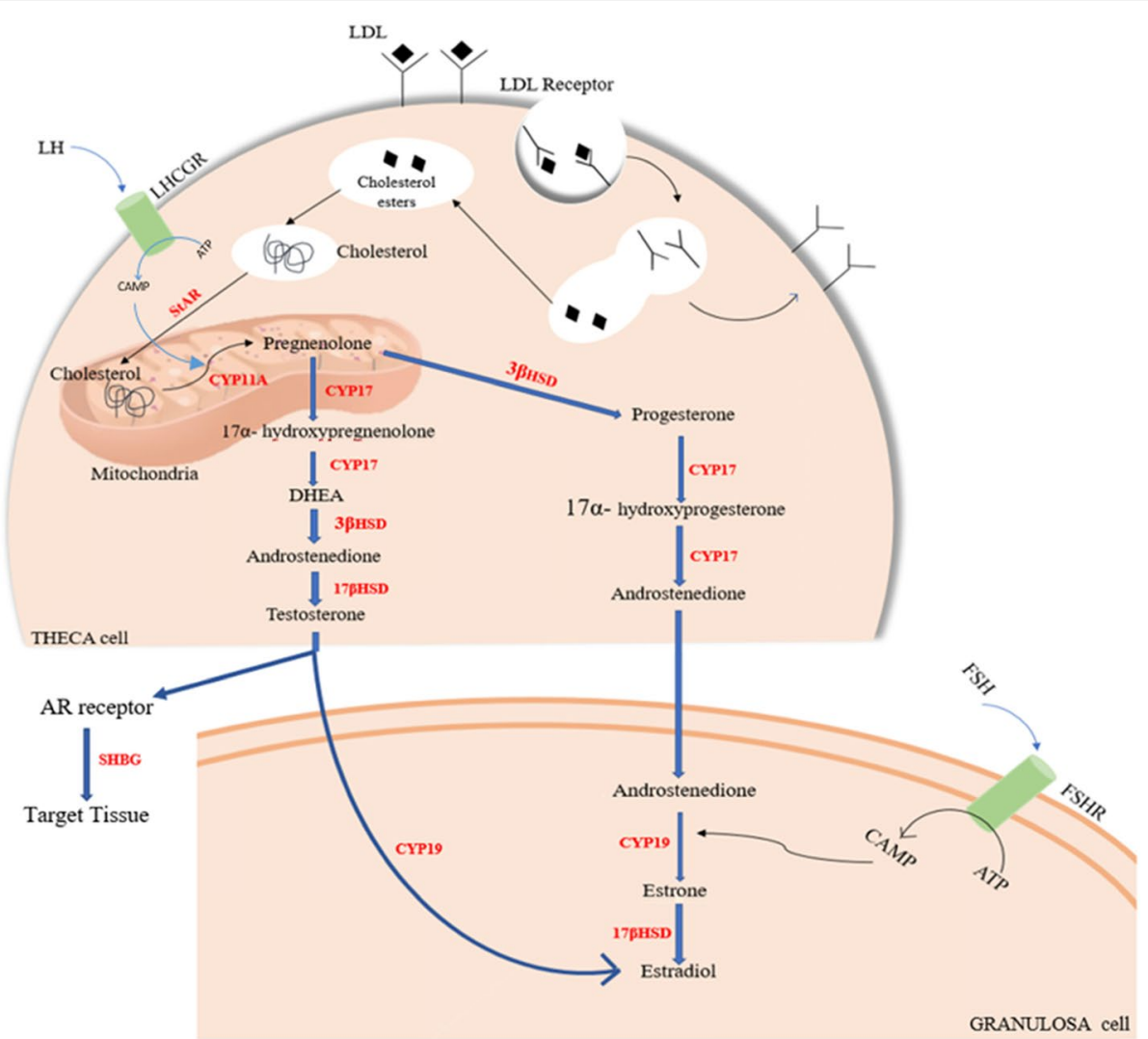

Fig. 2 Schematic diagram of Steroidogenesis pathway and the enzymes involved in the biosynthesis. Abbreviations: LHCGR, luteinizing

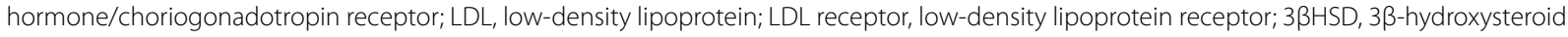
dehydrogenase; StAR, steroidogenic acute regulatory protein; CAMP, cyclic adenosine monophosphate; ATP, adenosine triphosphate; FSH, follicle-stimulating hormone; FSHR, follicle-stimulating hormone receptor; LH, luteinizing hormone; CYP, Cytochrome P450; 17ßHSD, 17ß-hydroxysteroid dehydrogenase; DHEA, dehydroepiandrosterone; AR, androgen receptor; SHBG, sex hormone-binding globulin

have identified almost 100 susceptibility genes related to PCOS. The relationship between target genes and disease risk variants is determined using linkage and association studies within the population or families. A transmission disequilibrium test (TDT) in affected siblings with hyperandrogenemia and PCOS-related traits predicted a strong association of follistatin, a nominal association of CYP11A1 gene, and a strong genetic association D19S884 allelic marker around INSR gene with PCOS [34]. Polymorphisms in genes involved in metabolic or regulatory pathways of steroid hormone synthesis, gonadotropin action, and insulin-signaling pathways have been investigated as PCOS susceptibility genes; however, the precise role of these susceptibility genes has not yet been to be determined [20,35-38]. In contrast to candidate gene approaches that study relatively small samples, genome-wide association studies (GWAS) provide researchers with a more systematic, unbiased approach to exploring thousands of variants across the entire genome in both case and control individuals to discover the association of genetic variants in a complex disease like PCOS. Hence, 11 susceptibility loci mapping to DENND1A, THADA, LHCGR, FSHR, INSR, TOX3, YAP1, RAB5B, c9orf3, HMGA2, and SUMO1P1/ZNF217 have been identified in Han Chinese populations, which are involved in various pathways [38, 39]. Polymorphism in CYP11A, CYP17, CYP19, CYP21, $\beta$ HSD, playing a role in the steroidogenesis pathway, results in the phenotypic expression of PCOS. Besides, the androgen receptor (AR) gene mediates the androgen level, and SHBG regulates the free serum androgen level; thus, all these genes may involve in the etiopathogenesis of PCOS. The candidate genes studies are the widely used technique to find the variants of the gene of interest and examined for correlation of androgen biosynthesis pathway and those affecting the secretion or action of insulin with PCOS etiology [40]. In addition, the name of the genes, the physiologic function affected by the genes, the studied population, and the type of single nucleotide polymorphisms or polymorphisms related with PCOS are detailed in this 
Table 1. Hence, in the below section, these genes, and their association with PCOS risk are described.

\section{CYP11A}

CYP11A is the side-chain cleavage enzyme (P450scc) located on chromosome 15q23-q24 [109] catalyses the conversion of cholesterol to pregnenolone, which is the first and rate-limiting enzymatic step in the biosynthesis of all steroid hormones [110]. P450scc is expressed in the ovary, more specifically in the theca interna and the granulosa cells of ovulatory follicles [111]. Apart from the ovary CYP11A is also expressed in the adrenal cortex, testis, and placenta [112]. There is an unusual exon/ intron junctional sequence starting with GC in the sixth intron in the CYP11A gene which is at least $20 \mathrm{~kb}$ with nine exons split by eight introns [113]. According to the linkage review, a CYP11A $5^{\prime}$ UTR (TTTTA) n pentanucleotide repeat polymorphism has a robust allelic association with hirsute PCOS patients [35]. Studies carried in the different ethnic groups showed varied association of these pentanucleotide repeat alleles with PCOS susceptibility. In the Caucasian population, a recent meta-analysis found a clear connection between the microsatellite (TTTTA) ${ }_{n}$ repeat polymorphism of CYP11A and an increased risk of PCOS [41]. The allelic variants of CYP11A and its polymorphism associated with serum testosterone level might be associated with androgen excess and hyperandrogenemia [42]. In the United States, South India, and Greece, a repeat polymorphism (TTTTA) $)_{n}$ in the promoter region of the CYP11A gene has been linked to PCOS in contrast to cases reported in Spanish, Chinese, Argentinian, Indian showed no association in women with PCOS [114116]. The meta-analysis findings revealed a connection between PCOS and a pentanucleotide repeat polymorphism in the CYP11A1 promoter [43]. Furthermore, the association of this gene with hirsutism and no significant association with ovulatory function indicates that CYP11a predominantly has a role in the development of hirsutism in PCOS [35]. Therefore, knowing the crucial role of this gene in ovarian steroidogenesis, all the studies imply the CYP11A gene as a possible genetic biomarker playing a major role in the pathogenesis of PCOS.

\section{CYP17}

CYP17 (P450c17), located on chromosome 10q24.3 [117], catalyzes two mixed-function oxidase reactions utilizing cytochrome $\mathrm{P} 450$ oxidoreductase and the microsomal electron transfer system [118]. The 17-hydroxylyase and 17-lyase activity of the P450c17 enzyme catalyses the conversion of pregnenolone to 17-hydroxypregnenolone and progesterone to 17-hydroxyprogesterone, followed by the cleavage of the 17-20 bond to create the
C19 steroids dehydroepiandrosterone and androstenedione [119]. The expression of CYP17 is observed in all steroidogenic tissues; however, in the adrenal gland and placenta, some species-related differences in the expression of the enzyme are reported. In the ovary, the expression of CYP17 is limited to theca cells that are the site of androgen production [120,121]. Although granulosa cells and luteal cells do not express CYP17, a recent report suggests that human luteinized granulosa cells in culture do express CYP17 [122]. The P450c17 enzyme has been shown to have increased activity and expression in the ovarian theca cells of PCOS women, along with the increased transactivation of the CYP17 promoter $[123,124]$. Studies have also shown the dysregulation of CYP17 expression of mRNA stability in PCOS theca cells [125]. Numerous mutations have been reported in the CYP17 gene and many studies have explained the polymorphism in this gene [126-129]. Studies have reported that the polymorphism in the 5'UTR region which involves a single base-pair change ( $\mathrm{T}-\mathrm{C})$, at a -34 position in the promoter region, regulates the expression of CYP17 and androgen levels, creating an additional Sp1 transcription factor binding site $[44,128]$. However, in previous studies conducted in British, American, Korean, Chinese, Thai, and Indian women with PCOS and Turkish adolescents, this polymorphism was not found to be a significant risk factor for PCOS growth [47]. Even though the CYP17 gene does not appear to be a candidate gene for PCOS pathophysiology, it plays a predominant role in developing hyperandrogenic phenotype and insulin resistance in women with PCOS $[45,46,130]$. Therefore, more detailed research is needed to understand the exact mechanism and role of the gene in the etiology of PCOS.

\section{CYP19}

CYP19 (P450arom), located on chromosome 15q21.1 $[131,132]$, catalyzes the transformation of the C19 androgens, androstenedione, and testosterone, to the C18 estrogens, estrone, and estradiol [133, 134]. The primary sites for the expression of P450arom are in the ovary, adipose stromal cells, placenta, bone, and various fetal tissues $[135,136]$. In the ovary, the granulosa cells of preovulatory follicles show higher expression of P450arom than do small follicles as well as in the corpus luteum of ovulatory women [137, 138]. Many studies have reported the deficiency of aromatase activity in patients with hyperandrogenism [139, 140]. Furthermore, there is a significant decrease in the activity of P450arom (irrespective of the BMI in women with PCOS) in both lean and obese women with PCOS [141]. Studies have reported that the reduced expression of CYP19A1 by the hypermethylation of the promoter region decreases the aromatase enzyme's overall 
Table 1 Candidate gene polymorphism associated with the pathogenesis of Polycystic ovary syndrome

\begin{tabular}{|c|c|c|c|c|}
\hline Gene & Polymorphism & Studied population & Physiological function & Reference \\
\hline \multirow[t]{4}{*}{ CYP11A } & 5'UTR (TTTTA)n pentanucleotide repeat & Samaritan & Hirsutism & [35] \\
\hline & $(\text { TTTTA })_{n}$ Microsatellite & Caucasian & Hyperandrogenism & [41] \\
\hline & & Greek & & [42] \\
\hline & $(\mathrm{TTTTA})_{n}$ Pentanucleotide repeat & Different & Hyperandrogenism & [43] \\
\hline \multirow[t]{7}{*}{ CYP17 } & $-34 \mathrm{~T} / \mathrm{C}$ polymorphism & British & Hyperandrogenism & [44] \\
\hline & & American & Insulin resistance & [44] \\
\hline & & Korean & & [44] \\
\hline & & Chinese & & [45] \\
\hline & & Thai & & [44] \\
\hline & & Indian & & [46] \\
\hline & & Turkish & & [47] \\
\hline \multirow[t]{12}{*}{ CYP19 } & rs2414096 polymorphism & African & Hyperandrogenism & [48] \\
\hline & & American & & [48] \\
\hline & & Caucasian & Decreased aromatase activity & [48] \\
\hline & & Chinese & & [49] \\
\hline & & Iranian & Increased E2 to T ratio & [50] \\
\hline & & Indian & & [51] \\
\hline & & Iraqi & & [52] \\
\hline & & Egyptian & & [53] \\
\hline & & Japanese & & [48] \\
\hline & & Chinese & & [54] \\
\hline & (TTTA)n Tetranucleotide repeat polymorphism & Greek & Hyperandrogenism & [55] \\
\hline & & Han Chinese & & [56] \\
\hline \multirow[t]{4}{*}{$17 \beta H S D$} & -71 A/G polymorphism & Greece & Hyperandrogenism & [57] \\
\hline & & Caucasian & & [58] \\
\hline & & African-American & & [59] \\
\hline & & Spanish & & [60] \\
\hline \multirow[t]{9}{*}{ SHBG } & TAAAA repeat Polymorphism & French & Hirsutism & {$[61,62]$} \\
\hline & & Greek & Late menarche & [63] \\
\hline & & Croatian & Decrease SHBG level & [64] \\
\hline & & Slovenian & & [65] \\
\hline & rs1799941 \& rs 727,428 & Chinese & Insulin resistance & [66] \\
\hline & & American & & [67] \\
\hline & D327N & Mediterranean & Hirsutism & [68] \\
\hline & & French & Androgen excess & [62] \\
\hline & E326K & Turkey & Metabolism of SHBG & [69] \\
\hline \multirow[t]{4}{*}{ AR } & Short CAG repeat & Chinese & Hyperandrogenism & [70] \\
\hline & & Caucasian & Increased androgen sensitivity & [71] \\
\hline & & & & {$[72,73]$} \\
\hline & GGN polymorphism & Chinese & Hyperandrogenism & [74] \\
\hline \multirow[t]{3}{*}{ INSR } & $\mathrm{C} / \mathrm{T}$ polymorphism & Caucasian & Insulin resistance & [75] \\
\hline & & Chinese & & [76] \\
\hline & & Korean & & [77] \\
\hline \multirow[t]{2}{*}{ LHCGR } & rs13405728 & Han Chinese & Hyperandrogenism & [78] \\
\hline & S312N & Sardinian & & [79] \\
\hline
\end{tabular}


Table 1 (continued)

\begin{tabular}{|c|c|c|c|c|}
\hline Gene & Polymorphism & Studied population & Physiological function & Reference \\
\hline \multirow[t]{5}{*}{ FSHR } & rs6165 & Turkish & & [47] \\
\hline & rs 6166 & Italian & & {$[80]$} \\
\hline & & Korean & & [81] \\
\hline & & Chinese & Difference in FSH \& PRL levels & {$[82,83]$} \\
\hline & rs2268361 & Chinese & Folliculogenesis & [39] \\
\hline GnRHR & rs104893836 & Israeli & & {$[84]$} \\
\hline \multirow[t]{4}{*}{$\mathrm{IL}-1$} & rs1800587 & Turkish & Biochemical, hormonal changes & {$[85]$} \\
\hline & & Caucasian & & {$[86]$} \\
\hline & & Caucasian & & {$[86]$} \\
\hline & rs16944 & Chinese & & {$[87]$} \\
\hline \multirow[t]{6}{*}{ PPARG } & Pro12Ala & Korean & Abdominal obesity & [88] \\
\hline & & & Metabolic dysfunction & \\
\hline & & & $\mathrm{BMI}$ & \\
\hline & & European & $\mathrm{BMI}$ & [89] \\
\hline & & Asian & & {$[89]$} \\
\hline & & Caucasian & $\begin{array}{l}\text { Insulin resistance } \\
\text { Hirsutism }\end{array}$ & {$[90-94]$} \\
\hline \multirow[t]{4}{*}{ VDR } & rs1544410, rs7975232 & South Indian & Biochemical, metabolic, endocrine & [95] \\
\hline & & Iranian & parameters & {$[96,97]$} \\
\hline & rs10735810, rs731236 & Turkish & & {$[98]$} \\
\hline & rs757343 & Austrian & & [99] \\
\hline \multirow[t]{6}{*}{ FTO } & rs9939609 & Chinese & Obesity & {$[100,101]$} \\
\hline & & UK & & {$[102]$} \\
\hline & & Finland & & [102] \\
\hline & & South Brazilian & & [103] \\
\hline & & Caucasian & & [104] \\
\hline & & East Asian & & [104] \\
\hline \multirow[t]{3}{*}{ ACE } & ACE I/D polymorphism & Caucasian & Hyperandrogenism & {$[105]$} \\
\hline & & Chinese & & {$[106]$} \\
\hline & & Turkey & & {$[107,108]$} \\
\hline
\end{tabular}

In addition, the name of the genes, the physiologic function affected by the genes, the studied population, and the type of single nucleotide polymorphisms or polymorphisms related with PCOS are detailed in this Table 1

Abbreviations: 17ßHSD 17ß-Hydroxysteroid Dehydrogenase, SHBG Sex hormone binding globulin, AR Androgen receptor, INSR Insulin receptor, FSHR Follicle stimulating hormone receptor, GnRHR Gonadotropin releasing hormone receptor, LHCGR Luteinizing hormone/chorionic gonadotropin receptor, IL-1 Interleukin-1, PPARG Peroxisome Proliferator Activated Receptor Gamma, VDR Vitamin D receptor, FTO Fat Mass and Obesity-Associated Protein, ACE Angiotensin Converting Enzyme

activity in women with PCOS varies [142]. The SNP of CYP19 rs2414096 showed significant association with reduced aromatase activity, increased estradiol to testosterone ratio $(\mathrm{E} 2 / \mathrm{T})$, hyperandrogenic phenotype, and PCOS development in African, American, Caucasian [48], Chinese [49], Iranian [50], Indian [51], Iraqi [52], Egyptian [53]. However, the association of CYP19 rs2414096 was not found statistically significant in Japanese women with PCOS [48]. Moreover, a tetranucleotide repeat polymorphism (TTTA) $n$ in the CYP19 gene with short alleles inhibits aromatase activity, resulting in hyperandrogenism and its association with increased testosterone levels, high LH: FSH ratios in women with PCOS has been reported [54-56, 143]. Studies have been reported increased levels of testosterone from follicular fluid of PCOS women, significantly reduce the expression of the aromatase enzyme in luteinized granulosa cells [144]. Therefore, different studies showed a significant association of aromatase enzyme in hyperandrogenism, and androgen biosynthesis represents a pivotal role of CYP19 as a susceptible gene in PCOS development. 


\section{CYP21}

CYP21 (P450c21) located on chromosome 6p21.3 [145]. The 21-hydroxylase enzyme catalyzes the hydroxylation of C21 steroids converting progesterone and 17-hydroxyprogesterone into 11-deoxycorticosterone and 11-deoxycortisol [146]. The major site for the expression of CYP21 is only in the adrenal cortex that is vital for the synthesis of adrenal-specific steroids, the glucocorticoids, cortisol, and corticosterone, and the mineralocorticoid, aldosterone $[147,148]$. The expression of the P450c21 enzyme is not detected in the kidney, liver, testis, or ovary [149]. Studies have reported an increased frequency of heterozygosity for CYP21 gene mutation in women with symptomatic hyperandrogenism, premature pubarche, and PCOS-like phenotype [150-152]. Furthermore, the frequency of heterozygosity for CYP21 mutations was found to be significantly higher in Spanish women with hirsutism, in both American and Greek children with premature pubarche, and in American adolescent girls with hyperandrogenism $[150,153,154]$. Overall, the CYP21 gene and its mutations do not appear to play a significant role in the predisposition of PCOS; however, it can play a minor role that further studies will solve.

\section{3ßHSD}

The $3 \beta$-Hydroxysteroid Dehydrogenase (3ßHSD) enzyme is located on chromosome 1p13.1 [155]. The 33HSD enzyme is essential for the biosynthesis of active steroid hormones, catalyzing the dehydrogenation and isomerization reaction converting delta5-3- $\beta$-hydroxysteroids, pregnenolone, and dehydroepiandrosterone into delta43-ketosteroids, progesterone, and androstenedione [156]. The expression of the $3 \beta \mathrm{HSD}$ isoform is tissue specific. The isoform $3 \beta \mathrm{HSD}$ II is expressed in the adrenal gland, ovary, and testes [157]. Studies have reported that the deficiency of the $3 \beta \mathrm{HSD}$ enzyme is associated with mild virilization and irregular or absent ovulation [158]. In Addition, the enzyme's deficiency in hyperandrogenic females is linked to insulin resistance and LH hypersecretion in PCOS patients $[159,160]$. There is a specific decrease in the expression of the 3ßHSD gene in luteinizing granulosa cells with large follicle size in women with polycystic ovaries [161]. The deficiency of the $3 \beta$ HSD gene and its association does not seem to play a significant role in PCOS development. Therefore, more research needs to be incorporated.

\section{7ßHSD}

The 17 $\beta$-Hydroxysteroid Dehydrogenase (17ßHSD) enzyme on chromosome 10p14-p15 [162] plays an essential role in steroidogenesis. The 17ßHSD enzymes catalyze the final step in the biosynthesis of active gonadal steroid, the conversion of androstenedione to estradiol and testosterone [159]. Type 5 of the $17 \beta$ HSD gene is exclusively expressed in the ovary and adrenal gland [58]. Immunohistochemical studies have shown the expression of the 17ßHSD type 5 gene in ovarian theca cells and corpus luteum [163]. Studies reported the increased frequency of $-71 \mathrm{~A} / \mathrm{G}$ polymorphism in the $17 \beta \mathrm{HSD}$ type 5 promoter region and its association in Caucasian women with PCOS. Furthermore, it is observed that this SNP increases the 17ßHSD type 5 promoter activity and its affinity for the transcription factors $\mathrm{Sp} 1 / \mathrm{Sp} 3$. Some menstrual irregularities are also observed due to the accumulation of androstenedione due to the deficiency of this enzyme [164]. The $-71 \mathrm{~A} / \mathrm{G}$ polymorphism in the $17 \beta \mathrm{HSD}$ type 5 gene is also associated with hyperandrogenemia and increased serum testosterone levels in women with PCOS but does not contribute to the pathophysiology of PCOS [59]. However, subsequent studies failed to identify the association between this SNP and hyperandrogenemia phenotype in African American, Caucasian, and premature pubarche in Spanish [57, $59,60,164]$. Another polymorphism of $17 \beta$ HSD type 5 gene, rs1937845 and rs12529, shows increased serum testosterone level, homeostasis model assessment of $\beta$-cell function (HOMA-B) index indicating the association of insulin resistance with hyperandrogenism in Chinese women [165]. 17ßHSD type 5 polymorphism does not influence the effect of oral contraceptive pills in Brazilian women with hirsutism and androgen excess [166]. Therefore, the polymorphism of the 17ßHSD type 5 gene may play a crucial role in the development of hyperandrogenemia and insulin resistance and can be regarded as a candidate gene for the etiopathogenesis of PCOS.

\section{SHBG}

The Sex hormone-binding globulin (SHBG) gene is located on chromosome 17p13.1 [167]. SHBG is primarily produced by hepatocytes, binds to androgens and estrogen with high affinity, thus, controls the levels of sex hormones within the circulation and regulates the access of target tissues to androgens $[168,169]$. The prime expression of SHBG receptors (RSHBG) is observed in sex-steroid-dependent cells and tissues which include ovaries, endometrium, colon, prostate, hypothalamus, breast, placenta, liver, epididymis, immune cells, and cardiomyocytes [170]. PCOS women are attributed with increased androgen levels and often present with insulin resistance and compensatory hyperinsulinemia, which inhibits the hepatic synthesis and secretion of SHBG resulting in low circulating SHBG concentrations [171]. Studies have reported that low serum SHBG levels in PCOS women result in hyperandrogenic symptoms such as 
hirsutism, acne, androgenic alopecia, and virilization [172-175]. Furthermore, some common genetic variations in the SHBG gene also influence circulating SHBG levels and may contribute to the PCOS phenotype [176, 177]. Studies have reported two novel coding region mutations, including one with abnormal glycosylation and the other is truncated SHBG synthesis in women, resulting in low SHBG levels and increased circulating free testosterone concentrations [178]. The correlation between a longer TAAAA repeats polymorphism and later menarche and lower SHBG levels in hirsute French women suggests that SHBG polymorphisms may play a genetic role $[61,62]$. In Greek PCOS women, longer allele genotype showed a positive association with lower SHBG levels [63]. The long TAAAA repeat alleles, on the other hand, did not display any association with PCOS aetiology in Croatian, Slovenian, or Chinese women [64-66]. Long SHBG alleles in combination with short CYP19 alleles resulted in low SHBG levels and increased testosterone levels, and elevated FAI, DHEAS, and T/E2 ratios in Greek women with PCOS [179]. Overall, the meta-analysis findings indicated insufficient evidence to draw a definitive connection between the TAAAA repeat polymorphism and PCOS risk, implying that it might not be a good predictor of PCOS risk [180]. Four single nucleotide polymorphisms (SNPs; rs1799941, rs6257, rs6259, and rs727428) have been identified as predictors of the development of type 2 diabetes in men and women and as modifiers of serum SHBG concentrations [181, 182]. However, a family-based and case-control study conducted in American and Mediterranean women with PCOS showed no direct association with PCOS risk. SNPs rs1799941 and rs727428 in the SHBG gene influenced serum SHBG concentrations after controlling for BMI and indexes of androgen excess and insulin resistance [67, 68]. Several studies have been published. Exon 8 contains a functional missense polymorphism that induces an amino acid transition from aspartic acid to asparagine $(\mathrm{D} 327 \mathrm{~N})$, which causes a delay in SHBG half-life and affects SHBG metabolism [62]. On the other hand, E326K, another missense polymorphism on exon eight, lowers SHBG levels and influences the SHBG metabolism independent of BMI, androgen, and insulin-related traits in PCOS women [69]. A recent study conducted in Bahraini women reported that specific SHBG variants affecting the SHBG concentrations and SHBG haplotypes spanning six polymorphisms were linked to increased or decreased PCOS susceptibility [183]. Thus, SHBG can be considered as a candidate gene playing a central role in the pathophysiology of PCOS.

\section{AR}

Androgen effects are facilitated by androgen receptors (AR). The AR gene is located on the $\mathrm{X}$-chromosome at Xq11-12 and with a genetic polymorphism in exon one characterized by a CAG trinucleotide repeat encoding polyglutamine restudies [184]. Increased androgen levels show association with inhibition of follicle development, anovulation, menstrual irregularities, and appearance of micro cysts in the ovaries [185, 186]. Exposure to intrauterine androgens in experimental models leads to the development of PCOS phenotype in adult life [187]. Theca interna cells of preantral follicles, granulosa cells of preantral and antral follicles, and both theca and granulosa cells of dominant follicles have all been found to contain AR [188]. The genetic polymorphism in the AR gene in exon one with CAG repeats indicates the association between AR activity and PCOS prevalence [189]. Studies have reported an increased frequency of short AR CAG repeats in PCOS women and may contribute to PCOS onset in both Chinese and Caucasian populations [70, 71]. Furthermore, in PCOS patients, this polymorphism causes AR upregulation and increased androgen sensitivity [72, 73]. However, no association of AR CAG repeat lengths in Indian [190] Slovene [191], Korean [192], and Croatian [193], was reported in PCOS women. Furthermore, few studies have also reported an association of CAG repeats length with higher serum testosterone levels in PCOS women [192-195]. Another study carried by Hickey et al. showed preferential expression of longer CAG repeats in infertile Australian PCOS women compared to fertile PCOS women that were also found positively correlated with serum testosterone levels. Additionally, a study comparing PCOS families found that sister pairs with diverse patterns of XCI were more likely to display clinically varied PCOS symptoms than sister pairs with identical XCI profiles, emphasizing the relevance of XCI in the pathogenesis of PCOS [196]. In contrast, Mifsud et al. found lower testosterone levels in PCOS patients with short CAG repeats [73]. On the other hand, a study conducted by Westberg et al. in premenopausal Swedish women found higher levels of serum androgens with fewer CAG repeats than women with longer repeats [197]. In addition to influencing AR expression, the XCI pattern can influence the expression of BMP15 (Xp11.2), a gene implicated in preovulatory follicular development [198]. Surprisingly, BMP15 increases FSH $\beta$ subunit transcription and secretion while not affect LH expression [199]. Calvo et al. investigated the relationships between AR-CAG allele length, XCI pattern, and hirsutism and compared AR CAG-BM levels to hormone (such as DHEAS) levels but found no significant difference links [200]. As a result, we believe the $\mathrm{XCI}$ pattern alters LH and FSH levels by directly altering 
the expression of gonadotropins or other genes required for folliculogenesis. Studies have also reported a significant GGN polymorphism and rs6152G/A polymorphism with Chinese PCOS women [74, 201]. The meta-analysis showed no significant association between CAG repeat lengths at AR and PCOS risk, unlikely to be the primary determining factor in PCOS etiology [202, 203]. Thus, androgen excess has a vital role in the developing hyperandrogenic phenotype in PCOS women and the pathophysiology of PCOS.

\section{StAR}

The Steroidogenic acute regulatory protein (StAR) is located on the short arm of chromosome 8p11.2 [204]. StAR protein acts as a transporter protein, which plays a major role in the transportation of cholesterol from the outer to the inner mitochondrial membrane in the first step of the steroidogenesis pathway $[205,206]$. The gene expression of steroidogenic enzymes including StAR was studied from granulosa and theca cells of women with PCOS. The follicles of theca cells showed increased expression of StAR in comparison to the size-matched control follicles which indicates the hyperstimulation of theca cells producing excessive amounts of androgens. However, in granulosa cells, there were no changes in the expression of StAR in follicles of PCOS women from control follicles, indicating the increased LH responsiveness of granulosa cells in PCOS women, which may contribute to arrested follicle development [207]. Another study conducted by Kahsar-Miller et al. showed no changes in expression of StAR in PCOS ovaries compared to normal healthy ovaries [208]. In Iranian PCOS women, however, no correlation was found between seven StAR SNPs [209].

\section{INSR}

The insulin receptor (INSR) gene is located on the short of chromosome 19 [210], which plays a significant role in insulin metabolism. The HAIR-AN syndrome (hyperandrogenism, insulin resistance, and acanthosis nigricans), a subset of PCOS marked by extreme insulin resistance, demonstrates the significance of insulin signaling in PCOS [211]. Insulin resistance may stimulate LH hypersecretion in the pituitary, increased testosterone production in theca cells, and P450scc activity in granulosa, and disturbs the follicular maturation, resulting in PCOS [212]. The polymorphism, C/T SNP at His1058 in exon 17 of the INSR gene has been significantly associated with Caucasian and Chinese PCOS women [75, 76]. However, in the Korean population, this polymorphism failed to confirm the association [77]. On the other hand, a novel $\mathrm{T} / \mathrm{C}$ polymorphism at Cys1008 in exon 17 was associated with decreased insulin sensitivity in Chinese
PCOS women [213]. Besides, linkage analysis studies predicted a microsatellite marker D19S884, located on chromosome 19p13.2, close to INSR gene associated with PCOS and was considered as a candidate gene [34, 214]. Other SNPs includes rs 225673 in intron 11 and rs8107575, rs2245648, rs2245649, rs2963, rs2245655, and rs2962 around exon 9 in the INSR gene have shown an association with PCOS. However, the impact on gene expression or its association with underlying genetic variation is still uncovered $[215,216]$. The results of metaanalyses showed no significant association between SNPs rs1799817 or rs2059806 with the development of PCOS. Nonetheless, SNP rs2059807 can be considered as a candidate risk factor for PCOS development [217]. Hence, all these studies so far suggest the association of the genetic variant in exon 17 of INSR with the pathophysiology of PCOS and INSR gene, being a crucial component of the insulin signaling pathway, could be a plausible candidate gene for PCOS.

\section{LHCGR}

The luteinizing hormone/choriogonadotropin receptor (LHCGR) gene, mapped on chromosome 2p16.3 [218] is a G-protein coupled receptor expressed predominantly in the granulosa cells of preovulatory follicles and is responsible for ovulation in response to the mid-cycle LH surge [219]. Inactivating mutations of LHCGR cause increased LH levels, menstrual irregularities, and infertility in women, while activating mutations cause hyperandrogenism [220]. A recent GWAS study identified the 2p16.3 region containing LHCGR loci to be associated with PCOS in Han Chinese and European populations [78, 221]. The LHCGR rs13405728 variant showed association with PCOS in Han Chinese women. However, it failed to explain association in European-derived and Caucasian population [78, 222-224], indicating that racial/ethnic background contributes to PCOS development. S312N, a nearby SNP in exon 10 (rs2293275) of LHCGR gene induces an amino acid substitution in the Sardinian population, was linked to PCOS [79]. The data obtained from the genomic study of LHCGR describes racial/ethnic background. Hence, independent ethnic research is needed to rule out the connection between gonadotropin receptor variants and an increased risk of PCOS.

\section{FSHR}

The Follicle-stimulating hormone receptor (FSHR), located on chromosome $2 \mathrm{p} 21$, is a G protein-coupled receptor, expressed in granulosa cells similarly to LHCGR [225]. FSHR stimulates oogenesis, follicle development, and gametogenesis, resulting in follicular maturation and proliferation of granulosa cells on binding with FSH 
[226]. Inactivating mutation in the FSHR gene results in hypogonadotropic hypogonadism and induces arrest of follicle development at the preantral stage [227]. A recent GWAS study reported the association of the FSHR gene with PCOS in the Han Chinese population and European-derived population $[39,78,221]$. The two variants in exon 10 of the FSHR gene rs6165 (Thr307Ala) and rs6166 (Asn680Ser) have been studied in association with PCOS [47, 80-83]. However, the meta-analysis results showed the association of SNP rs6166 (Asn680Ser) showed with PCOS women, while, the SNP rs6165 (Thr307Ala) failed to show any association with PCOS [228]. Another polymorphism, rs2268361 showed an association with PCOS in the Chinese population [39] but not in Dutch [229]. The relationship between the genotype of the FSHR variants and PCOS and how exactly it contributes to PCOS development is not clear. Hence, the genetic variants of the FSHR gene studied irrespective of the race difference can be considered as a risk factor for PCOS.

\section{GnRHR}

Gonadotropin-releasing hormone receptor (GnRHR) is a G-protein coupled receptor found in the anterior pituitary's gonadotroph membrane and many extra-pituitary tissues such as the ovary, placenta, breast, and cancer tissues [230, 231]. GnRH on binding with its receptor GnRHR activates the phosphatidylinositol-Ca2+ second messenger system and modifies LH and FSH synthesis and secretion [232]. The polymorphism of the GnRHR gene was detected using PCR-RFLP assay and the findings revealed that TCC, CCC, and CCT haplotypes increased the risk of PCOS, while TTT, TCT, and TTC haplotypes reduced the risk [233]. Three sisters from a consanguineous family with PCOS were examined in a recent genome-wide study using whole-exome sequencing. Sanger sequencing of the rs104893836 variant in the first exon of the GnRHR and suggested that genetic variation in the hypothalamus-pituitary axis seems to play role in the pathogenesis of PCOS [84]. The genetic alteration in $\mathrm{GnRH}$ and its receptor might play a role in the development of PCOS. However, susceptible variants in this gene as a PCOS risk factor are still not discovered.

\section{IL-1}

Interleukin 1 (IL-1) is a crucial multifunctional proinflammatory cytokine composed of three distinct cytokines: IL- $1 \alpha$, IL-1 $\beta$, and the physiologic antagonist IL-1 receptor antagonist (IL-1RA) [234]. IL1 $\alpha$ and IL1 $\beta$ are located on chromosome $2 q 14.2$ within a $430 \mathrm{~kb}$ area [235]. In reproductive biology, IL-1 is thought to alter ovulation, fertilisation, and implantation due to its inflammatory traits [236]. According to research, the polymorphism rs1800587 $(-889 \mathrm{C} / \mathrm{T})$ reduces IL-1 gene transcription through altering IL- $1 \alpha$ protein expression in ovarian tissue in Caucasian population [85, 86]. Moreover, the first association study of the two IL- $1 \beta$ polymorphism rs 16,944 (-511C/T) and rs 1,143,634 (+3953 $\mathrm{C} / \mathrm{T}$ ) and PCOS development was conducted by Kolbus et al. in Caucasian population but failed to find a correlation. However, another study conducted in Chinese population showed that the rs $16,944(-511 \mathrm{C} / \mathrm{T})$ polymorphism showed association with developing PCOS by somehow altering the IL- $1 \beta$ production. However, no association was observed while studying the rs 1,143,634 $(+3953 \mathrm{C} / \mathrm{T})[86,87]$. Hence, these findings suggest that IL-1 family gene polymorphism may be an influential marker for the risk of PCOS.

\section{PPARG}

Peroxisome proliferator activated receptor gamma (PPARG) is a ligand-activated transcription factor located on chromosome 3p24.2-p25 [237]. It impacts adipocyte differentiation, insulin sensitivity, lipid metabolism, and the development of atherosclerosis [238]. PPARG has many single nucleotide polymorphisms (SNPs), the most studied of which is PPARG Pro12Ala. Studies have showed the association of Pro12Ala polymorphism with abdominal obesity in Korean PCOS women with metabolic dysfunction since PPARG plays an essential role in adipose tissue metabolism [88]. The Ala allele carriers reported significant higher BMI waist circumference, waist to hip ratio and sum of skinfolds than non-carriers in PCOS cohort [239]. A meta-analysis conducted in European and Asian population reported a positive relationship between Pro12Ala polymorphism and BMI [89]. In addition, some studies found a significant increase in insulin sensitivity (lower HOMA-IR), as well as lower fasting insulin and glucose levels in Caucasian population [90-93] and a lower hirsutism score in PCOS women carrying the Pro12Ala G allele [94]; however, others, found no link between fasting glucose and insulin or changes in HOMA-IR in PCOS women carrying the Pro12Ala G allele [240-243]. Even though considerable research on Pro12Ala polymorphism in diverse ethnic populations of PCOS women have been undertaken, the majority of the results have been inconsistent, if not wholly contradicting.

\section{KISS 1}

Kisspeptin (KISS) is a neuropeptide located on chromosome 1q32 [244]. Kiss 1 gene stimulates the activity of GPR54, a G protein-coupled transmembrane receptor present in GnRH neurons, and hence increases LH levels [245]. Kisspeptin has been implicated in the control of the HPG axis in numerous studies since its discovery, at the cell, animal, and even human levels [246-248]. In 
specific trials, kisspeptin treatment has been shown to result in an almost 2-fold increase in LH levels, with a minor or non-existent increase in FSH levels [249-251]. Additionally, Kisspeptin has been shown to have a direct influence on GnRH neurons upstream in terms of depolarization directly, increased firing rate, and up-regulated expression of GnRH mRNA, which explains the elevated LH/FSH ratio found in prior studies [252-255]. Although the primary research has revealed a possible link between the KISS1 system and the HPG axis, it is still unclear whether the plasma/serum kisspeptin concentration is higher in PCOS women than in general. Kisspeptin levels were more significant in PCOS women than in controls in some research [256-258], while other studies found similar or negatively linked results $[259,260]$. As a result, plasma/serum kisspeptin levels are likely to be related with serum LH levels, and therefore with the pathophysiology of PCOS.

\section{VDR}

The Vitamin D receptor (VDR) Gene is located on chromosome 12q13.11 [261]. The VDR belongs to the nuclear receptor superfamily and is found in a various tissues, including the intestine, kidney, parathyroid gland, pancreatic beta cells, and bones, all of which are important in calcium homeostasis maintenance. The active form of vitamin $\mathrm{D}, 1,25(\mathrm{OH}) 2-\mathrm{D} 3$, regulates gene transcription in target organs by binding to the nuclear vitamin $\mathrm{D}$ receptor (VDR). In addition, for optimal VDR-DNA interaction, the VDR forms a heterodimer with the retinoid-X receptor (RXR) [262]. It is also expressed in human ovarian tissue and endometrium, and it has been shown to play a role in the steroidogenesis of sex hormones [263265]. Irregularities in calcium balance may disturb follicular growth in women, affecting the aetiology of PCOS [266]. Although studies demonstrate that vitamin D deficiency might promote metabolic syndrome and insulin resistance in PCOS patients, it is unclear if vitamin D is associated with endocrine and reproductive parameters in PCOS patients [264, 267]. Several studies on VDR gene polymorphisms revealed a link between VDR BsmI (rs1544410),), ApaI (rs7975232), FokI (rs10735810), and TaqI (rs731236) and PCOS risk in South Indian women and Iranian women $[95,96,268]$. Ranjzad et al. also looked at the relationship between the FokI, BsmI, ApaI, TaqI, and Tru9I (rs757343) polymorphisms and biochemical and metabolic parameters in Iranian PCOS women. The findings demonstrated substantial relationships between lower levels of sex hormone binding globulin (SHBG) and both VDR BsmI "GG" and adiponectin (ADIPOQ) BsmI "CC" genotypes, implying that the "G" allele is a risk factor for PCOS in homozygotes [97]. Bagheri and colleagues investigated the FokI and BsmI variants of the VDR gene in the genetic predisposition to PCOS in Iranian and Azeri Turkish women. Their findings revealed no statistically significant differences in PCOS susceptibility in the examined group [98]. Furthermore, Wehr and colleagues performed a cohort analysis in Austrian women with PCOS to assess the relationship between VDR polymorphisms and PCOS susceptibility. They found no link between VDR BsmI, FokI, and TaqI polymorphisms and anthropometric, endocrine, or metabolic parameters [99]. According to the findings of many studies, the association between VDR gene polymorphisms and PCOS in different ethnicities is debatable. However, it may play a significant role in the pathophysiology of PCOS.

\section{FTO}

The human Fat Mass and Obesity-Associated Protein (FTO) gene is found on chromosome 16q12.2 and is expressed in nearly all tissues [269, 270]. The protein encoded by the FTO gene is a 2-oxoglutarate-dependent nucleic acid demethylase involved in energy metabolism [271]. A genome-wide association analysis published in 2007 found that FTO is linked to body mass index (BMI) and obesity [269]. Obesity is a prevalent feature in PCOS patients, with more than half of all PCOS cases being overweight or obese [272]. A common single nucleotide polymorphism (SNP) (rs9939609) in the first intron of the FTO gene with a $\mathrm{T}$ to A change has recently been extensively researched in PCOS women. However, the results of various studies are conflicting. Studies found a strong correlation between FTO and PCOS in the Chinese, UK, Finland, and South Brazilian populations [100103], while others revealed a link between FTO and BMI in PCOS women, although they do not appear to have a significant role in the reproductive phenotypes of PCOS [273-275]. Cai et al. found that the FTO rs9939609 polymorphism was linked with PCOS risk among East Asians but not in the Caucasian population [104]. As a result, it is fair to speculate that the FTO gene may have a role in the pathogenesis of PCOS via BMI and/or obesity.

\section{RXR}

Human sebocytes express retinoid X receptors (RXRs), members of the steroid/thyroid hormone superfamily [276]. Retinol is critical for female reproduction, and retinoids have been implicated in ovarian steroidogenesis, oocyte maturation, and corpus luteum development $[277,278]$. Retinoids have been shown to increase steroid hormone production in peripheral steroidogenic tissues. Retinoid therapy elevated the expression of steroidogenic acute regulatory protein (StAR) in mice Leydig cells, resulting in steroidogenesis potentiation [279]. All-transand/or 9-cis-retinoic acid enhanced gene expression of 
StAR, CYP17A1, and P450scc, as well as testosterone and dehydroepiandrosterone synthesis in human ovarian thecal cells [280]. When PCOS cell extracts were compared to standars extracts, the conversion of retinol to retinaldehyde was enhanced, indicating that the enzymes responsible for retinol metabolism are present in theca cells and may be changed in PCOS [281]. RXR boosted the expression of CYP19, a crucial regulator in oestrogen synthesis, and increased the synthesis of estradiol, which protects hippocampus neurons against OGD and inflammatory stimuli, demonstrating that RXR is responsible for CYP19 expression [282]. These findings revealed that retinoids had a significant impact on theca cell androgen production as well as the expression of steroidogenic enzyme genes. More research is needed to understand the pattern of expression of enzymes involved in retinol metabolism/retinoid production in ovarian cells, as well as their functional significance in retinoid action in PCOS.

\section{VEGF}

The Vascular Epithelial Growth Factor (VEGF) is a homodimer glycoprotein that is expressed in granulosa and thecal cells and is known to play a role in the pathophysiology of PCOS [283]. It is involved in angiogenesis, follicular vascularisation, and intra-follicular oxygenation, and hence influences follicle maturation, oocyte quality, fertilisation, and embryo development [11, 28, 284]. PCOS is associated with increased stromal vascularity, which may be due to a dysregulation of numerous angiogenic factors, including VEGF. Daghestani et al. reported that VEGF levels in obese PCOS women were four times greater than in non-PCOS obese women, consistent with prior research indicating higher levels of VEGF in PCOS patients [285, 286]. As a result, the evidence so far suggests that VEGF may have a role in the aetiology of PCOS.

\section{ACE}

Angiotensin converting enzyme (ACE), a critical factor in the conversion of Angiotensin I to Angiotensin II, is found in a various organs, including the ovaries. ACE and its products, in addition to regulating blood pressure and fluid balance, play an essential role in regulating ovarian function through follicular development, oocyte maturation, ovulation, and follicular atresia [287]. The inter-individual variability in plasma $\mathrm{ACE}$ concentration has been linked to an insertion (I)/deletion (D) polymorphism involving a 287-bp DNA sequence located in intron 16 of the ACE gene, known as the ACE I/D polymorphism [288]. A recent meta-analysis found a positive association between this polymorphism and PCOS risk in Caucasians, but no such association in Asians [289]. Koika et al. discovered a positive link between I/D polymorphism and PCOS in cases of hyperandrogenism but not in situations of non-hyperandrogenism [105]. Another study in a Chinese population discovered that the DD genotype was related to higher testosterone concentrations when compared to the II genotype [106]. Moreover, similar associations were discovered for fasting insulin and homeostatic model assessment for insulin resistance (HOMA-IR) in PCOS patients in Turkey $[107,108]$. Furthermore, obese women with PCOS have greater total renin levels than age- and BMI-matched controls, but not ACE activity or aldosterone levels [290]. Based on considerable research conducted in various ethnic populations, the presence of a relationship between ACE I/D polymorphism and PCOS is debatable. This shows that, whereas I/D polymorphisms in the ACE gene were not the major etiological cause, they may be linked to worsened clinical symptoms of PCOS.

\section{Conclusion and future perspective}

Polycystic ovary syndrome remains a complex endocrine paradox characterized mainly by surplus androgen production resulting in metabolic and gynecological concerns in affected individuals. The fact that $70 \%$ of women diagnosed with PCOS go on to become infertile makes it a concerning issue. With infertility on the rise and PCOS as a significant cause in women, early detection and treatment play critical roles in improving quality of life. As a result, we tried to look for unique polymorphisms of the chosen candidate gene that may be employed in the diagnosis and screening of PCOS. Although androgen excess is the primary cause of PCOS pathogenesis, the brain dysfunction route, which encompasses the hypothalamus-pituitary-ovarian axis, could also be the cause of PCOS. It is difficult to determine due to inhibition in the feedback loops involving the hypothalamus, pituitary, and ovary and should be investigated further to determine the aetiopathogenesis of PCOS. Hyperandrogenism can be studied by inducing PCOS phenotypes in fetal, neonatal, and prepubertal giving excess androgenic treatments to animal models. Another mechanism is using transgenic models for studying neuroendocrine dysfunction (HPO axis). Furthermore, obesity plays a vital part in the aetiology of PCOS, and most individuals with the condition are overweight or obese; nonetheless, these illnesses are not regarded diagnostic criteria for PCOS because not all obese women exhibit hyperandrogenism. Insulin resistance, which is present in the most obese and/or PCOS patients, is a risk factor for developing glucose intolerance and type 2 diabetes mellitus. Insulin resistance is higher and more severe in obese PCOS individuals than in non-obese PCOS patients. 
The current review has summarized the influence of polymorphism in genes involved in steroidogenesis, gonadotropin action and control, insulin regulation that govern PCOS susceptibility and phenotypic heterogeneity. A candidate gene technique has been used in studies to give conclusive evidence for including or excluding any gene. Many genes are included in this article. However, only a handful have been proved to influence steroidogenesis pathways in PCOS women: CYP11A, CYP17, CYP19, 17HSD, SHBG, AR, RXR, KISS1, VDR. In addition, the genes LHCGR, INSR, FSHR, and GnRHR have been demonstrated to affect gonadotropin activity and control in PCOS women. Obesity and metabolic consequences are linked to the genes FTO, VEGF, ACE, and PPARG, revealing that obese PCOS patients had greater levels of Interleukin-1, PPARG, FTO, and VEGF when compared to control women. However, family investigations have revealed that PCOS has a genetic basis and that no single gene can fully explain the disease. Additionally, candidate gene approach has not provided conclusive results for any of the susceptible gene. As a result, the genetic markers studied thus far could aid in diagnosing the syndrome and its phenotypes, allowing for earlier involvement in co-morbidities and more personalized care.

\footnotetext{
Abbreviations

PCOS: Polycystic ovary syndrome; USG: Ultrasonography; NIH: National Institute of Health; PCOM: Polycystic ovarian morphology; ESHRE: European Society of Human Reproduction and Embryology; ASRM: The American Society for Reproductive Medicine; AES: Androgen Excess Society; GnRH: Gonadotropin-releasing hormone; GnRHR: Gonadotropin-releasing hormone receptor; LH: Luteinizing hormone; LHCGR: Luteinizing hormone/choriogonadotropin receptor; FSH: Follicle stimulating hormone; FSHR: Folliclestimulating hormone receptor; ACTH: Adrenocorticotrophic hormone; HSDs: Hydroxysteroid dehydrogenases; StAR: Steroidogenic acute regulatory protein;

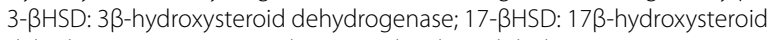
dehydrogenase; SHBG: Sex hormone-binding globulin; RSHBG: Receptor sex hormone-binding globulin; AR: Androgen receptor; TDT: Transmission disequilibrium test; INSR: Insulin receptor; GWAS: Genome-wide association studies; DENND1A: DENN Domain-Containing Protein 1A; THADA: Thyroid Adenoma Associated Protein; TOX3: Tox High Mobility Group Box Family Member 3; YAP1: Yes-Associated Protein 1; RAB5B: Ras-Related Protein Rab5B; C9orf3: Chromosome 9 Open Reading Frame 3; HMGA2: High-Mobility Group AT-Hook 2; SUMO1P1/ZNF217: Pseudogene 1 / Zinc Finger Protein 217; HOMA-B: Homeostasis Model Assessment Of $\beta$-Cell Function; HAIR-AN: Hyperandrogenism, insulin resistance, and acanthosis nigricans; P450 scc: Side-chain cleavage enzyme; P450c17: 17-hydroxylase enzyme; P450arom: Aromatase enzyme; P450c21: 21-hydroxylase enzyme; NADPH: Nicotinamide Adenine Dinucleotide Phosphate; SNP: Single nucleotide polymorphism; FAl: Free Androgen Index; DHEAS: Dehydroepiandrosterone sulfate; E2: Estradiol; T: Testosterone; UTR: Untranslated Region; XCl: X-chromosome inactivation; BMP: Bone morphogenetic protein; BMI: Basal Metabolic Index; HPG: Hypothalamus-Pituitary-Gonadal; IL: Interleukin; ILRA: Interlekin-1 receptor antagonist; PPARG: Peroxisome proliferator activated receptor gamma; KISS: Kisspeptin;VDR: Vitamin-D receptor; RXR: Retinoid X receptor; FTO: Fat Mass and Obesity-Associated Protein; VEGF: Vascular Epithelial Growth Factor; ACE: Angiotensin converting enzyme.
}

\section{Acknowledgements}

We would like to acknowledge CSIR-UGC-NET for providing Junior Research fellowship to Hiral Chaudhary. We would like to acknowledge Department of Biochemistry and Forensic Science for providing necessary facility.

\section{Authors' contributions}

$\mathrm{HC}$ assisted with data collecting, writing, and manuscript preparation. JP assisted with data collection. The critical review was carried out by NKJ and RJ. The article was read and approved by all writers.

\section{Funding}

Not applicable.

\section{Availability of data and materials}

Not applicable.

\section{Declarations}

Ethics approval and consent to participate

The study was approved by Institutional Ethics Committee (IEC) of University School of Sciences, Gujarat University.

\section{Consent for publication}

Not applicable.

\section{Competing interests}

The authors declare that they have no competing interest.

\section{Author details}

${ }^{1}$ Department of Biochemistry and Forensic Science, University School of Sciences, Gujarat University, Ahmedabad, Gujarat 380009, India. ${ }^{2}$ Department of Life Science, University School of Sciences, Gujarat University, Ahmedabad, Gujarat 380009, India.

Received: 13 July 2021 Accepted: 9 September 2021

Published online: 26 September 2021

\section{References}

1. Goodarzi MO, Dumesic DA, Chazenbalk G, Azziz R. Polycystic ovary syndrome: etiology, pathogenesis and diagnosis. Nat Rev Endocrinol. 2011;7(4):219-31.

2. Kabel AM. Polycystic ovarian syndrome: insights into pathogenesis, diagnosis, prognosis, pharmacological and non-pharmacological treatment. Pharm Bioprocess. 2016:4(1):7-12.

3. Lizneva D, Suturina L, Walker W, Brakta S, Gavrilova-Jordan L, Azziz R, et al. Criteria, prevalence, and phenotypes of polycystic ovary syndrome. Fertil Steril. 2016;106(1):6-15.

4. Bharathi RV, Swetha S, Neerajaa J, Madhavica JV, Janani DM, Rekha $\mathrm{S}$, et al. An epidemiological survey: effect of predisposing factors for PCOS in Indian urban and rural population. Middle East Fertil Soc J. 2017;22(4):313-6.

5. Knochenhauer E, Key T, Kahsar-Miller M, Waggoner W, Boots L, Azziz R, et al. Prevalence of the polycystic ovary syndrome in unselected black and white women of the southeastern United States: a prospective study. J Clin Endocrinol Metab. 1998:83(9):3078-82.

6. Ferriman D, Gallwey JD. Clinical assessment of body hair growth in women. J Clin Endocrinol Metab. 1961;21(11):1440-7.

7. Wild RA. Long-term health consequences of PCOS. Hum Reprod Update. 2002;8(3):231-41.

8. Goodarzi MO, Carmina E, Azziz R. Dhea, dheas and pcos. J Steroid Biochem Mol Biol. 2015;145:213-25.

9. Fenichel P, Rougier C, Hieronimus S, Chevalier N. Which origin for polycystic ovaries syndrome: Genetic, environmental or both?. Annales d'endocrinologie. 2017;78(3):176-15.

10. Jonard S, Dewailly D. The follicular excess in polycystic ovaries, due to intra-ovarian hyperandrogenism, may be the main culprit for the follicular arrest. Hum Reprod Update. 2004;10(2):107-17. 
11. Qiao J, Feng HL. Extra-and intra-ovarian factors in polycystic ovary syndrome: impact on oocyte maturation and embryo developmental competence. Hum Reprod Update. 2011;17(1):17-33.

12. Ben-Shlomo I. The polycystic ovary syndrome: what does insulin resistance have to do with it? Reprod BioMed Online. 2003;6(1):36-42.

13. Ehrman DA, Barnes RB, Rosenfield RL. Polycystic ovary syndrome as a form of functional ovarian hyperandrogenism due to dysregulation of androgen secretion. Endocr Rev. 1995;16(3):322-53.

14. Kawadzki J, Dunaif A, Givens J, Haseltine F, Merriam GJA. Diagnostic criteria for polycystic ovary syndrome: a rational approach. In: Polycystic ovary syndrome. Cambridge: Blackwell Scientific; 1992. p. 377.

15. ESHRE TR, A-SPCWG. Revised 2003 consensus on diagnostic criteria and long-term health risks related to polycystic ovary syndrome. Fertil Steril. 2004;81(1):19-25.

16. Azziz R, Carmina E, Dewailly D, Diamanti-Kandarakis E, Escobar-Morreale HF, Futterweit W, et al. Criteria for defining polycystic ovary syndrome as a predominantly hyperandrogenic syndrome: an androgen excess society guideline. J Clin Endocrinol Metab. 2006;91(11):4237-45.

17. Ropelato MG, Garcia Rudaz MC, Escobar ME, Bengolea SV, Calcagno ML, Veldhuis JD, et al. Acute effects of testosterone infusion on the serum luteinizing hormone profile in eumenorrheic and polycystic ovary syndrome adolescents. J Clin Endocrinol Metab. 2009;94(9):3602-10.

18. Blank SK, McCartney CR, Helm KD, Marshall JC, editors. Neuroendocrine effects of androgens in adult polycystic ovary syndrome and female puberty. In: Seminars in reproductive medicine. New York: Copyright@ 2007 by Thieme Medical Publishers, Inc.; 2007.

19. Waldstreicher J, Santoro NF, Hall JE, Filicori M, Crowley JRWF. Hyperfunction of the hypothalamic-pituitary axis in women with polycystic ovarian disease: indirect evidence for partial gonadotroph desensitization. J Clin Endocrinol Metab. 1988;66(1):165-72.

20. Franks S. Polycystic ovary syndrome. N Engl J Med. 1995;333(13):853-61.

21. Skorupskaite K, George JT, Anderson RA. The kisspeptin-GnRH pathway in human reproductive health and disease. Hum Reprod Update. 2014;20(4):485-500

22. Abbott D, Barnett D, Bruns C, Dumesic D. Androgen excess fetal programming of female reproduction: a developmental aetiology for polycystic ovary syndrome? Hum Reprod Update. 2005;11(4):357-74.

23. Rosenfield RL, Barnes RB, Jose'F C, Lucky AW. Dysregulation of cytochrome P450c17a as the cause of polycystic ovarian syndrome. Fertil Steril. 1990;53(5):785-91.

24. Kirschner MA, Bardin CW. Androgen production and metabolism in normal and virilized women. Metabolism. 1972;21(7):667-88.

25. Balen A H, Conway G, Homburg R, Legro R. (Eds.) Polycystic Ovary Syndrome: A Guide to Clinical Management (1st ed.). UK: CRC Press; 2006.

26. Miller WL. Molecular biology of steroid hormone synthesis. Endocr Rev. 1988;9(3):295-318.

27. Dadachanji R, Shaikh N, Mukherjee S. Genetic variants associated with hyperandrogenemia in PCOS pathophysiology. Genet Res Int. 2018;2018:7624932

28. Diamanti-Kandarakis E, Argyrakopoulou G, Economou F, Kandaraki E, Koutsilieris M. Defects in insulin signaling pathways in ovarian steroidogenesis and other tissues in polycystic ovary syndrome (PCOS). J Steroid Biochem Mol Biol. 2008;109(3-5):242-6.

29. Rodriguez Paris V, Bertoldo MJ. The mechanism of androgen actions in PCOS etiology. Med Sci. 2019;7(9):89.

30. Nelson VL, Legro RS, Strauss JF III, MCAllister JM. Augmented androgen production is a stable steroidogenic phenotype of propagated theca cells from polycystic ovaries. Mol Endocrinol. 1999;13(6):946-57.

31. Legro RS, Driscoll D, Strauss JF, Fox J, Dunaif A. Evidence for a genetic basis for hyperandrogenemia in polycystic ovary syndrome. Proc Natl Acad Sci. 1998;95(25):14956-60.

32. Legro RS, Bentley-Lewis R, Driscoll D, Wang SC, Dunaif A. Insulin resistance in the sisters of women with polycystic ovary syndrome: association with hyperandrogenemia rather than menstrual irregularity. J Clin Endocrinol Metab. 2002;87(5):2128-33.

33. Franks S, McCarthy M. Genetics of ovarian disorders: polycystic ovary syndrome. Rev Endocr Metab Disord. 2004;5(1):69-76.

34. Urbanek M, Legro RS, Driscoll DA, Azziz R, Ehrmann DA, Norman RJ, et al. Thirty-seven candidate genes for polycystic ovary syndrome: strongest evidence for linkage is with follistatin. Proc Natl Acad Sci. 1999:96(15):8573-8
35. Gharani N, Waterworth DM, Batty S, White D, Gilling-Smith C, Conway GS, et al. Association of the steroid synthesis gene CYP11a with polycystic ovary syndrome and hyperandrogenism. Hum Mol Genet. 1997;6(3):397-402.

36. Dunaif A, Xia J, Book C-B, Schenker E, Tang Z. Excessive insulin receptor serine phosphorylation in cultured fibroblasts and in skeletal muscle. A potential mechanism for insulin resistance in the polycystic ovary syndrome. J Clin Invest. 1995;96(2):801-10.

37. O'Rahilly S, Choi WH, Patel P, Turner RC, Flier JS, Moller DE. Detection of mutations in insulin-receptor gene in NIDDM patients by analysis of single-stranded conformation polymorphisms. Diabetes. 1991;40(6):777-82.

38. Conway GS, Avey C, Rumsby G. Genetics: The tyrosine kinase domain of the insulin receptor gene is normal in women with hyperinsulinaemia and polycystic ovary syndrome. Hum Reprod. 1994;9(9):1681-3.

39. Shi Y, Zhao H, Shi Y, Cao Y, Yang D, Li Z, et al. Genome-wide association study identifies eight new risk loci for polycystic ovary syndrome. Nat Genet. 2012;44(9):1020.

40. Goodarzi M O. Looking for polycystic ovary syndrome genes: rational and best strategy. Semin Reprod Med. 2008;26(1):5-13.

41. Shen W, LiT, Hu Y, Liu H, Song M. Common polymorphisms in the CYP1A1 and CYP11A1 genes and polycystic ovary syndrome risk: a meta-analysis and meta-regression. Arch Gynecol Obstet. 2014;289(1):107-18

42. Diamanti-Kandarakis E, Bartzis MI, Bergiele AT, Tsianateli TC, Kouli CR. Microsatellite polymorphism (tttta) n at -528 base pairs of gene CYP11 a influences hyperandrogenemia in patients with polycystic ovary syndrome. Fertil Steril. 2000;73(4):735-41.

43. Yu M, Feng R, Sun X, Wang H, Wang H, Sang Q, et al. Polymorphisms of pentanucleotide repeats (tttta) $n$ in the promoter of CYP11A1 and their relationships to polycystic ovary syndrome (PCOS) risk: a meta-analysis. Mol Biol Rep. 2014;41(7):4435-45.

44. Sharp L, Cardy AH, Cotton SC, Little J. CYP17 gene polymorphisms: prevalence and associations with hormone levels and related factors. A HuGE review. Am J Epidemiol. 2004;160(8):729-40.

45. Li Y, Liu F, Luo S, Hu H, Li X-H, Li S-W. Polymorphism T $\rightarrow$ C of gene CYP17 promoter and polycystic ovary syndrome risk: a meta-analysis. Gene. 2012;495(1):16-22.

46. Pusalkar M, Meherji P, Gokral J, Chinnaraj S, Maitra A. CYP11A1 and CYP17 promoter polymorphisms associate with hyperandrogenemia in polycystic ovary syndrome. Fertil Steril. 2009;92(2):653-9.

47. Unsal T, Konac E, Yesilkaya E, Yilmaz A, Bideci A, Onen HI, et al. Genetic polymorphisms of FSHR, CYP17, CYP1A1, CAPN10, INSR, SERPINE1 genes in adolescent girls with polycystic ovary syndrome. J Assist Reprod Genet. 2009;26(4):205-16.

48. Sowers MR, Wilson AL, Kardia SR, Chu J, Ferrell R. Aromatase gene (CYP 19) polymorphisms and endogenous androgen concentrations in a multiracial/multiethnic, multisite study of women at midlife. Am J Med. 2006;119(9):S23-30.

49. Jin J-L, Sun J, Ge H-J, Cao Y-X, Wu X-K, Liang F-J, et al. Association between CYP19 gene SNP rs2414096 polymorphism and polycystic ovary syndrome in Chinese women. BMC Med Genet. 2009;10(1):139.

50. Mehdizadeh A, Kalantar SM, Sheikhha MH, Aali BS, Ghanei A. Association of SNP rs. 2414096 CYP19 gene with polycystic ovarian syndrome in Iranian women. Int J Reprod Biomed. 2017;15(8):491.

51. Ranjith R, Rani U, Nagarajeshwari C, Unnisa W, Nalini S, Jahan P. Genetics: androgen associated gene polymorphism (s) in women with polycystic ovary syndrome from South Indian population; 2011

52. Al-Salihi AR, Hamdan FB, Mutib MT. Effect of CYP19 gene on polycystic ovary syndrome phenotype in Iraqi women. Iraqi J Med Sci. 2015;13(3):272-8.

53. Mostafa RA, Al-Sherbeeny MM, Abdelazim IA, Fahmy AA, Farghali MM Abdel-Fatah MA, et al. Relation between aromatase gene CYP19 variation and hyperandrogenism in polycystic ovary syndrome Egyptian women. J Infertil Reprod Biol. 2016;4:1-5.

54. Xu P, Zhang X, Xie G, Zhang C, Shen S, Zhang X, et al. The (TTTA) n polymorphism in intron 4 of CYP19 and the polycystic ovary syndrome risk in a Chinese population. Mol Biol Rep. 2013;40(8):5041-7.

55. Lazaros L, Xita N, Hatzi E, Takenaka A, Kaponis A, Makrydimas G, et al. CYP19 gene variants affect the assisted reproduction outcome 
of women with polycystic ovary syndrome. Gynecol Endocrinol. 2013;29(5):478-82.

56. Hao C, Zhang N, Qu Q, Wang X, Gu HF, Chen ZJ. Evaluation of the association between the CYP19 tetranucleotide (TTTA) n polymorphism and polycystic ovarian syndrome (PCOS) in Han Chinese women. Neuroendocrinol Lett. 2010;31(3):370-4.

57. Goodarzi MO, Jones MR, Antoine HJ, Pall M, Chen Y-DI, Azziz R, et al. Nonreplication of the type $517 \beta$-hydroxysteroid dehydrogenase gene association with polycystic ovary syndrome. J Clin Endocrinol Metab. 2008;93(1):300-3.

58. Qin K-N, Rosenfield RL. Expression of 17ß-hydroxysteroid dehydrogenase type 5 in human ovary: a pilot study. J Soc Gynecol Investig. 2000;7(1):61-4.

59. Marioli DJ, Saltamavros AD, Vervita V, Koika V, Adonakis G, Decavalas G, et al. Association of the 17-hydroxysteroid dehydrogenase type 5 gene polymorphism (-71A/G HSD17B5 SNP) with hyperandrogenemia in polycystic ovary syndrome (PCOS). Fertil Steril. 2009;92(2):648-52.

60. Petry CJ, Ong KK, Wingate DL, de Zegher F, Ibáñez L, Dunger DB, et al. Lack of association between common polymorphisms in the 17ß-hydroxysteroid dehydrogenase type $V$ gene (HSD17B5) and precocious pubarche. J Steroid Biochem Mol Biol. 2007;105(1-5):176-80.

61. Xita N, Tsatsoulis A, Stavrou I, Georgiou I. Association of SHBG gene polymorphism with menarche. Mol Hum Reprod. 2005;11(6):459-62.

62. Cousin P, Calemard-Michel L, Lejeune H, Raverot G, Yessaad N, EmptozBonneton A, et al. Influence of SHBG gene pentanucleotide TAAAA repeat and D327N polymorphism on serum sex hormone-binding globulin concentration in hirsute women. J Clin Endocrinol Metab. 2004;89(2):917-24.

63. Xita N, Tsatsoulis A, Chatzikyriakidou A, Georgiou I. Association of the (TAAAA) $n$ repeat polymorphism in the sex hormone-binding globulin (SHBG) gene with polycystic ovary syndrome and relation to SHBG serum levels. J Clin Endocrinol Metab. 2003;88(12):5976-80.

64. Baldani DP, Skrgatic L, Cerne JZ, Oguic SK, Gersak BM, Gersak K. Association between serum levels and pentanucleotide polymorphism in the sex hormone binding globulin gene and cardiovascular risk factors in females with polycystic ovary syndrome. Mol Med Rep. 2015;11(5):3941-7.

65. Ferk P, Teran N, Gersak K. The (TAAAA) $n$ microsatellite polymorphism in the SHBG gene influences serum SHBG levels in women with polycystic ovary syndrome. Hum Reprod. 2007;22(4):1031-6.

66. Zhao J, Chen Z, Zhao Y, Zhao L, Wang L, Li Y, et al. Study on the (TAAAA) $n$ repeat polymorphism in sex hormone-binding globulin gene and the SHBG serum levels in putative association with the glucose metabolic status of Chinese patients suffering from polycystic ovarian syndrome in Shandong province. Zhonghua Yi Xue Yi Chuan Xue Za Zhi. 2005:22(6):644-7.

67. Wickham EP III, Ewens KG, Legro RS, Dunaif A, Nestler JE, Strauss JF III, et al. Polymorphisms in the SHBG gene influence serum SHBG levels in women with polycystic ovary syndrome. J Clin Endocrinol Metab. 2011;96(4):E719-E27.

68. Martínez-García MÁ, Gambineri A, Alpañés M, Sanchón R, Pasquali R, Escobar-Morreale HF. Common variants in the sex hormone-binding globulin gene (SHBG) and polycystic ovary syndrome (PCOS) in Mediterranean women. Hum Reprod. 2012;27(12):3569-76.

69. Hacıhanefioğlu B, Aybey B, Hakan Özön Y, Berkil H, Karşıdağ K. Association of anthropometric, androgenic and insulin-related features with polymorphisms in exon 8 of SHBG gene in women with polycystic ovary syndrome. Gynecol Endocrinol. 2013;29(4):361-4.

70. Xia Y, Che Y, Zhang X, Zhang C, Cao Y, Wang W, et al. Polymorphic CAG repeat in the androgen receptor gene in polycystic ovary syndrome patients. Mol Med Rep. 2012;5(5):1330-4.

71. Lin LH, Baracat MC, Maciel GA, Soares JM Jr, Baracat EC. Androgen receptor gene polymorphism and polycystic ovary syndrome. Int J Gynecol Obstet. 2013;120(2):115-8.

72. Shah NA, Antoine HJ, Pall M, Taylor KD, Azziz R, Goodarzi MO, et al. Association of androgen receptor CAG repeat polymorphism and polycystic ovary syndrome. J Clin Endocrinol Metab. 2008;93(5):1939-45.

73. Mifsud A, Ramirez S, Yong E. Androgen receptor gene CAG trinucleotide repeats in anovulatory infertility and polycystic ovaries. J Clin Endocrinol Metab. 2000;85(9):3484-8.
74. Yuan C, Gao C, Qian Y, Liu Y, Jiang S-W, Cui Y, et al. Polymorphism of CAG and GGN repeats of androgen receptor gene in women with polycystic ovary syndrome. Reprod BioMed Online. 2015;31(6):790-8.

75. Siegel S, Futterweit W, Davies TF, Concepcion ES, Greenberg DA, Villanueva $\mathrm{R}$, et al. AC/T single nucleotide polymorphism at the tyrosine kinase domain of the insulin receptor gene is associated with polycystic ovary syndrome. Fertil Steril. 2002;78(6):1240-3.

76. Chen Z, Shi Y, Zhao Y, Li Y, Tang R, Zhao L, et al. Correlation between single nucleotide polymorphism of insulin receptor gene with polycystic ovary syndrome. Zhonghua Fu Chan Ke Za Zhi. 2004;39(9):582.

77. Lee E-J, Yoo K-J, Kim S-J, Lee S-H, Cha KY, Baek K-H, et al. Single nucleotide polymorphism in exon 17 of the insulin receptor gene is not associated with polycystic ovary syndrome in a Korean population. Fertil Steril. 2006;86(2):380-4.

78. Chen Z-J, Zhao H, He L, Shi Y, Qin Y, Shi Y, et al. Genome-wide association study identifies susceptibility loci for polycystic ovary syndrome on chromosome 2p16. 3, 2p21 and 9q33. 3. Nat Genet. 2011;43(1):55-9.

79. Capalbo A, Sagnella F, Apa R, Fulghesu A, Lanzone A, Morciano A, et al. The $312 \mathrm{~N}$ variant of the luteinizing hormone/choriogonadotropin receptor gene (LHCGR) confers up to 2. 7-fold increased risk of polycystic ovary syndrome in a S ardinian population. Clin Endocrinol. 2012;77(1):113-9.

80. Dolfin E, Guani B, Lussiana C, Mari C, Restagno G, Revelli A, et al. FSHreceptor Ala307Thr polymorphism is associated to polycystic ovary syndrome and to a higher responsiveness to exogenous FSH in Italian women. J Assist Reprod Genet. 2011;28(10):925-30.

81. Gu B-H, Park J-M, Baek K-H. Genetic variations of follicle stimulating hormone receptor are associated with polycystic ovary syndrome. Int J Mol Med. 2010;26(1):107-12.

82. Wu X-Q, Xu S-M, Liu J-F, Bi X-Y, Wu Y-X, Liu J, et al. Association between FSHR polymorphisms and polycystic ovary syndrome among Chinese women in north China. J Assist Reprod Genet. 2014;31(3):371-7.

83. Du J, Zhang W, Guo L, Zhang Z, Shi H, Wang J, et al. Two FSHR variants, haplotypes and meta-analysis in Chinese women with premature ovarian failure and polycystic ovary syndrome. Mol Genet Metab. 2010;100(3):292-5.

84. Caburet S, Fruchter RB, Legois B, Fellous M, Shalev S, Veitia RA. A homozygous mutation of GNRHR in a familial case diagnosed with polycystic ovary syndrome. Eur J Endocrinol. 2017;176:K9-K14.

85. Eser B, Islimye Taskin M, Hismiogullari AA, Aksit H, Bodur AS. The effects of IL-1A and IL-6 genes polymorphisms on gene expressions, hormonal and biochemical parameters in polycystic ovary syndrome. J Obstet Gynaecol. 2017;37(3):358-62.

86. Kolbus A, Walch K, Nagele F, Wenzl R, Unfried G, Huber JC. Interleukin-1 alpha but not interleukin-1 beta gene polymorphism is associated with polycystic ovary syndrome. J Reprod Immunol. 2007;73(2):188-93.

87. Yang Y, Qiao J, Tang R-X, Li M-Z. Genotype and haplotype determination of interleukin (IL) $1 \beta$ (g. - 511C> T and g.+ 3954C> T) and IL-1RN in polycystic ovary syndrome. Fertil Steril. 2010;94(1):384-6.

88. Kim KS, Choi SM, Shin SU, Yang HS, Yoon Y. Effects of peroxisome proliferator-activated receptor-y2 Pro12Ala polymorphism on body fat distribution in female Korean subjects. Metabolism. 2004;53(12):1538-43.

89. Tönjes A, Scholz M, Loeffler M, Stumvoll M. Association of Pro12Ala polymorphism in peroxisome proliferator-activated receptor $\gamma$ with pre-diabetic phenotypes: meta-analysis of 57 studies on nondiabetic individuals. Diabetes Care. 2006;29(11):2489-97.

90. Hara M, Alcoser SY, Qaadir A, Beiswenger KK, Cox NJ, Ehrmann DA, et al. Insulin resistance is attenuated in women with polycystic ovary syndrome with the Pro12Ala polymorphism in the PPARY gene. J Clin Endocrinol Metab. 2002;87(2):772-5.

91. Baldani DP, Skrgatic L, Cerne JZ, Ferk P, Simunic V, Gersak K. Association of PPARG Pro12Ala polymorphism with insulin sensitivity and body mass index in patients with polycystic ovary syndrome. Biomed Rep. 2014;2(2):199-206.

92. San-Millán JL, Escobar-Morreale HF. The role of genetic variation in peroxisome proliferator-activated receptors in the polycystic ovary syndrome (PCOS): an original case-control study followed by systematic review and meta-analysis of existing evidence. Clin Endocrinol. 2010;72(3):383-92.

93. Dragojevič J, Ostanek B, Mencej-Bedrač S, Komadina R, Preželj J, Marc J. PPARG gene promoter polymorphism is associated with non-traumatic 
hip fracture risk in the elderly Slovenian population: a pilot study. Clin Biochem. 2011:44(13):1085-9.

94. Hahn S, Fingerhut A, Khomtsiv U, Khomtsiv L, Tan S, Quadbeck B, et al. The peroxisome proliferator activated receptor gamma Pro12Ala polymorphism is associated with a lower hirsutism score and increased insulin sensitivity in women with polycystic ovary syndrome. Clin Endocrinol. 2005;62(5):573-9.

95. Siddamalla S, Reddy TV, Govatati S, Erram N, Deenadayal M, Shivaji $S$, et al. Vitamin D receptor gene polymorphisms and risk of polycystic ovary syndrome in South Indian women. Gynecol Endocrinol. 2018;34(2):161-5.

96. Mahmoudi T. Genetic variation in the vitamin D receptor and polycystic ovary syndrome risk. Fertil Steril. 2009;92(4):1381-3.

97. Ranjzad F, Mahban A, Shemirani Al, Mahmoudi T, Vahedi M, Nikzamir $A$, et al. Influence of gene variants related to calcium homeostasis on biochemical parameters of women with polycystic ovary syndrome. J Assist Reprod Genet. 2011;28(3):225-32.

98. Bagheri M, Isa Abdi R, Jazani NH, Nanbakhsh F. Lack of association of vitamin D receptor Fokl (rs10735810)(C/T) and Bsml (rs1544410)(A/G) genetic variations with polycystic ovary syndrome risk: A case-control study from Iranian azeri turkish women. Maedica. 2012;7(4):303.

99. Wehr E, Trummer O, Giuliani A, Gruber H-J, Pieber TR, ObermayerPietsch B. Vitamin D-associated polymorphisms are related to insulin resistance and vitamin D deficiency in polycystic ovary syndrome. Eur J Endocrinol. 2011;164(5):741.

100. Yan Q, Hong J, Gu W, Zhang Y, Liu Q, Su Y, et al. Association of the common rs9939609 variant of FTO gene with polycystic ovary syndrome in Chinese women. Endocrine. 2009;36(3):377-82.

101. Li T, Wu K, You L, Xing X, Wang P, Cui L, et al. Common variant rs9939609 in gene FTO confers risk to polycystic ovary syndrome. PLoS One. 2013:8(7):e66250.

102. Barber T, Bennett A, Groves C, Sovio U, Ruokonen A, Martikainen H, et al. Association of variants in the fat mass and obesity associated (FTO) gene with polycystic ovary syndrome. Diabetologia. 2008;51(7):1153-8.

103. Ramos RB, Spritzer PM. FTO gene variants are not associated with polycystic ovary syndrome in women from southern Brazil. Gene. 2015;560(1):25-9.

104. Cai X, Liu C, Mou S. Association between fat mass-and obesity-associated (FTO) gene polymorphism and polycystic ovary syndrome: a meta-analysis. PLoS One. 2014;9(1):e86972.

105. Koika V, Georgopoulos NA, Piouka A, Roupas ND, Karela A, Armeni AK, et al. Increased frequency of the DI genotype of the angiotensin-I converting enzyme and association of the II genotype with insulin resistance in polycystic ovary syndrome. Eur J Endocrinol. 2012;166(4):695.

106. Che Y, Cao Y, Wu X, Sun H-X, Liang F, Yi L, et al. Association between ACE gene I/D polymorphisms and hyperandrogenism in women with polycystic ovary syndrome (PCOS) and controls. BMC Med Genet. 2009;10(1):1-6.

107. Celik O, Yesilada E, Hascalik S, Celik N, Sahin I, Keskin L, et al. Angiotensin-converting enzyme gene polymorphism and risk of insulin resistance in PCOS. Reprod BioMed Online. 2010;20(4):492-8.

108. Karabulut A, Turgut $S$, Turgut $G$. Angiotensin converting enzyme gene insertion/deletion polymorphism in patients with polycystic ovary syndrome. Gynecol Endocrinol. 2010;26(6):393-8.

109. Chung B-C, Matteson KJ, Voutilainen R, Mohandas T, Miller WL. Human cholesterol side-chain cleavage enzyme, P450scc: cDNA cloning, assignment of the gene to chromosome 15, and expression in the placenta. Proc Natl Acad Sci. 1986;83(23):8962-6.

110. Miller WL. Androgen biosynthesis from cholesterol to DHEA. Mol Cell Endocrinol. 2002;198(1-2):7-14.

111. Oonk R, Parker K, Gibson J, Richards J. Rat cholesterol side-chain cleavage cytochrome P-450 (P-450scc) gene. Structure and regulation by CAMP in vitro. J Biol Chem. 1990;265(36):22392-401.

112. Shan B, Zhou L, Yang S, Yan M, Wang Z, Ouyang Y, et al. Association between polycystic ovary syndrome (PCOS) and CYP11A1 polymorphism in Hainan, China: a case-control study. Int J Clin Exp Pathol. 2016;9(1):230-6

113. Morohashi K-I, Sogawa K, Omura T, Fujii-kuriyama Y. Gene structure of human cytochrome P-450 (SCC), cholesterol desmolase. J Biochem. 1987;101(4):879-87.
114. Reddy KR, Deepika M, Supriya K, Latha KP, Rao SL, Rani VU, et al. CYP11A1 microsatellite (tttta) n polymorphism in PCOS women from South India. J Assist Reprod Genet. 2014;31(7):857-63.

115. San Millán JL, Sancho J, Calvo RM, Escobar-Morreale HF. Role of the pentanucleotide (tttta) $n$ polymorphism in the promoter of the CYP11a gene in the pathogenesis of hirsutism. Fertil Steril. 2001;75(4):797-802.

116. Li T, Guijin Z. Role of the pentanucleotide (tttta) n polymorphisms ofCYP11a gene in the pathogenesis of hyperandrogenism in chinese women with polycystic ovary syndrome. J Huazhong Univ Sci Technol Med Sci. 2005;25(2):212-4.

117. Fan Y-S, Sasi R, Lee C, Winter J, Waterman M, Lin C. Localization of the human CYP17 gene (cytochrome P45017a) to 10q24. 3 by fluorescence in situ hybridization and simultaneous chromosome banding. Genomics. 1992;14(4):1110-1.

118. Matteson KJ, Picado-Leonard J, Chung B-C, Mohandas T, Miller WL. Assignment of the gene for adrenal P450cl7 (steroid 17a-hydr0xylase/ 17, 20 lyase) to human chromosome 10. J Clin Endocrinol Metab. 1986;63(3):789-91.

119. Prapas N, Karkanaki A, Prapas I, Kalogiannidis I, Katsikis I, Panidis D. Genetics of polycystic ovary syndrome. Hippokratia. 2009;13(4):216.

120. Sasano H, Okamoto M, Mason J, Simpson E, Mendelson C, Sasano N, et al. Immunolocalization of aromatase, 17a-hydroxylase and sidechain-cleavage cytochromes P-450 in the human ovary. Reproduction. 1989;85(1):163-9.

121. Tamura T, Kitawaki J, Yamamoto T, Osawa Y, Kominami S, Takemorit S, et al. Immunohistochemical localization of 17a-hydroxylase/C17-20 lyase and aromatase cytochrome P-450 in polycystic human ovaries. J Endocrinol. 1993;139(3):503-NP.

122. Moran F, VandeVoort C, Overstreet J, Lasley B, Conley AJ. Molecular target of endocrine disruption in human luteinizing granulosa cells by 2, 3, 7, 8-tetrachlorodibenzo-p-dioxin: inhibition of estradiol secretion due to decreased 17a-hydroxylase/17, 20-lyase cytochrome P450 expression. Endocrinology. 2003;144(2):467-73.

123. Wickenheisser JK, Quinn PG, Nelson VL, Legro RS, Strauss JF III, McAllister JM, et al. Differential activity of the cytochrome P450 17a-hydroxylase and steroidogenic acute regulatory protein gene promoters in normal and polycystic ovary syndrome theca cells. J Clin Endocrinol Metab. 2000;85(6):2304-11.

124. Wickenheisser JK, Nelson-DeGrave VL, Quinn PG, McAllister JM. Increased cytochrome P450 17a-hydroxylase promoter function in theca cells isolated from patients with polycystic ovary syndrome involves nuclear factor-1. Mol Endocrinol. 2004;18(3):588-605.

125. Wickenheisser JK, Nelson-DeGrave VL, McAllister JM. Dysregulation of cytochrome P450 17a-hydroxylase messenger ribonucleic acid stability in theca cells isolated from women with polycystic ovary syndrome. J Clin Endocrinol Metab. 2005:90(3):1720-7.

126. Yanase T. 17a-hydroxylase/17, 20-lyase defects. J Steroid Biochem Mol Biol. 1995;53(1-6):153-7.

127. Franks $S$, White $D$, Gilling-Smith C, Carey A, Waterworth D, Williamson $R$, et al. Hypersecretion of androgens by polycystic ovaries: the role of genetic factors in the regulation of cytochrome P450c17a. Baillieres Clin Endocrinol Metab. 1996;10(2):193-203.

128. Carey AH, Waterworth D, Patel $K$, White D, Little J, Novelli P, et al. Polycystic ovaries and premature male pattern baldness are associated with one allele of the steroid metabolism gene CYP17. Hum Mol Genet. 1994;3(10):1873-6.

129. Miyoshi Y, Iwao K, Ikeda N, Egawa C, Noguchi S. Genetic polymorphism in CYP17 and breast cancer risk in Japanese women. Eur J Cancer. 2000;36(18):2375-9.

130. Perez MS, Cerrone GE, Benencia H, Marquez N, De Piano E, Frechtel GD. Polymorphism in CYP11alpha and CYP17 genes and the etiology of hyperandrogenism in patients with polycystic ovary syndrome. Medicina. 2008;68(2):129.

131. Chen S, Besman MJ, Sparkes RS, Zollman S, Klisak I, Mohandas T, et al. Human aromatase: cDNA cloning, southern blot analysis, and assignment of the gene to chromosome 15. DNA. 1988;7(1):27-38.

132. Takayama K, Suzuki T, Bulun SE, Sasano H, Yilmaz B, Sebastian S, editors. Organization of the human aromatase p450 (CYP19) gene. In: Seminars in reproductive medicine. New York: Copyright@ 2004 by Thieme Medical Publishers, Inc:; 2004. 
133. Simpson ER, Mahendroo MS, Means GD, Kilgore MW, Hinshelwood MM, Graham-Lorence S, et al. Aromatase cytochrome P450, the enzyme responsible for estrogen biosynthesis. Endocr Rev. 1994;15(3):342-55.

134. Graham-Lorence S, Khalil MW, Lorence MC, Mendelson CR, Simpson ER. Structure-function relationships of human aromatase cytochrome P-450 using molecular modeling and site-directed mutagenesis. J Biol Chem. 1991;266(18):11939-46.

135. Kamat A, Hinshelwood MM, Murry BA, Mendelson CR. Mechanisms in tissue-specific regulation of estrogen biosynthesis in humans. Trends Endocrinol Metab. 2002;13(3):122-8.

136. Simpson ER, Clyne C, Rubin G, Boon WC, Robertson K, Britt K, et al. Aromatase-a brief overview. Annu Rev Physiol. 2002;64(1):93-127.

137. Hickey GJ, Chen S, Besman MJ, Shively JE, Hall PF, Gaddy-Kurten D, et al. Hormonal regulation, tissue distribution, and content of aromatase cytochrome P450 messenger ribonucleic acid and enzyme in rat ovarian follicles and corpora lutea: relationship to estradiol biosynthesis. Endocrinology. 1988;122(4):1426-36.

138. Doody KJ, Lorence MC, Mason JI, Simpson ER. Expression of messenger ribonucleic acid species encoding steroidogenic enzymes in human follicles and corpora lutea throughout the menstrual cycle. J Clin Endocrinol Metab. 1990;70(4):1041-5.

139. de Medeiros SF, Barbosa JS, Yamamoto MMW. Comparison of steroidogenic pathways among normoandrogenic and hyperandrogenic polycystic ovary syndrome patients and normal cycling women. J Obstet Gynaecol Res. 2015;41(2):254-63.

140. Petry C, Ong K, Michelmore K, Artigas S, Wingate D, Balen A, et al. Association of aromatase (CYP 19) gene variation with features of hyperandrogenism in two populations of young women. Hum Reprod. 2005;20(7):1837-43.

141. Chen J, Shen S, Tan Y, Xia D, Xia Y, Cao Y, et al. The correlation of aromatase activity and obesity in women with or without polycystic ovary syndrome. J Ovarian Res. 2015;8(1):11.

142. Yu Y-Y, Sun C-X, Liu Y-K, Li Y, Wang L, Zhang W, et al. Promoter methylation of CYP19A1 gene in Chinese polycystic ovary syndrome patients. Gynecol Obstet Investig. 2013;76(4):209-13.

143. Xita N, Lazaros L, Georgiou I, Tsatsoulis A. CYP19 gene: a genetic modifier of polycystic ovary syndrome phenotype. Fertil Steril. 2010;94(1):250-4.

144. Yang F, Ruan Y-C, Yang Y-J, Wang K, Liang S-S, Han Y-B, et al. Follicular hyperandrogenism downregulates aromatase in luteinized granulosa cells in polycystic ovary syndrome women. Reproduction. 2015;150(4):289-96.

145. Morel Y, Bristow J, Gitelman SE, Miller WL. Transcript encoded on the opposite strand of the human steroid 21-hydroxylase/complement component C4 gene locus. Proc Natl Acad Sci. 1989;86(17):6582-6.

146. Mellon SH, Miller WL. Extraadrenal steroid 21-hydroxylation is not mediated by P450c21. J Clin Invest. 1989;84(5):1497-502.

147. Rice DA, Kronenberg M, Mouw AR, Aitken L, Franklin A, Schimmer B, et al. Multiple regulatory elements determine adrenocortical expression of steroid 21-hydroxylase. J Biol Chem. 1990;265(14):8052-8.

148. Wijesuriya SD, Zhang G, Dardis A, Miller WL. Transcriptional regulatory elements of the human gene for cytochrome P450c21 (steroid 21-hydroxylase) lie within intron 35 of the linked C4B gene. J Biol Chem. 1999;274(53):38097-106.

149. Parker KL, Chaplin DD, Wong M, Seidman J, Smith JA, Schimmer BP. Expression of murine 21-hydroxylase in mouse adrenal glands and in transfected $\mathrm{Y} 1$ adrenocortical tumor cells. Proc Natl Acad Sci. 1985;82(23):7860-4.

150. Witchel SF, Lee PA, Suda-Hartman M, Hoffman EP. Hyperandrogenism and manifesting heterozygotes for 21-hydroxylase deficiency. Biochem Mol Med. 1997;62(2):151-8.

151. Blanché H, Vexiau P, Clauin S, Le Gall I, Fiet J, Mornet E, et al. Exhaustive screening of the 21-hydroxylase gene in a population of hyperandrogenic women. Hum Genet. 1997;101(1):56-60.

152. Witchel S, Aston C. The role of heterozygosity for CYP21 in the polycystic ovary syndrome. J Pediatr Endocrinol Metab. 2000;13:1315.

153. Escobar-Morreale HF, San Millán JL, Smith RR, Sancho J, Witchel SF. The presence of the 21-hydroxylase deficiency carrier status in hirsute women: phenotype-genotype correlations. Fertil Steril. 1999;72(4):629-38.
154. Dacou-Voutetakis C, Dracopoulou M. High incidence of molecular defects of the CYP21 gene in patients with premature adrenarche. J Clin Endocrinol Metab. 1999:84(5):1570-4.

155. Bain P, Meisler M, Payne A, Taylor B. The genes encoding gonadal and nongonadal forms of 3 [beta]-hydroxysteroid dehydrogenase/[Delta] [sup 5]-[Delta] [sup 4] isomerase are closely linked on mouse chromosome 3. Genomics;(United States). 1993;16(1):219-23.

156. Payne A, Bain P, Clarke T, Sha L, Youngblood G, Hammond S. Hormonal regulation and tissue-specific expression of steroidogenic enzymes. Molecular basis of reproductive endocrinology. Springer New York; 1993. p. 65-91.

157. Morel Y, Mébarki F, Rhéaume E, Sanchez R, Forest MG, Simard J. Structure-function relationships of $3 \beta$-hydroxysteroid dehydrogenase: contribution made by the molecular genetics of $3 \beta$-hydroxysteroid dehydrogenase deficiency. Steroids. 1997;62(1):176-84

158. Bongiovanni AM. Acquired adrenal hyperplasia: with special reference to 3 beta-hydroxysteroid dehydrogenase. Fertil Steril. 1981;35(6):599-608.

159. Blomquist $\mathrm{CH}$. Kinetic analysis of enzymic activities: prediction of multiple forms of 17ß-hydroxysteroid dehydrogenase. J Steroid Biochem Mol Biol. 1995;55(5-6):515-24.

160. Carbunaru G, Prasad P, Scoccia B, Shea P, Hopwood N, Ziai F, et al. The hormonal phenotype of nonclassic $3 \beta$-hydroxysteroid dehydrogenase (HSD3B) deficiency in hyperandrogenic females is associated with insulin-resistant polycystic ovary syndrome and is not a variant of inherited HSD3B2 deficiency. J Clin Endocrinol Metab. 2004;89(2):783-94.

161. Doldi N, Grossi D, Destefani A, Gessi A, Ferrari A. Polycystic ovary syndrome: evidence for reduced $3 \beta$-hydroxysteroid dehydrogenase gene expression in human luteinizing granulosa cells. Gynecol Endocrinol. 2000;14(1):32-7.

162. Rheault P, Dufort I, Soucy P. Assignment1 of HSD17B5 encoding type 517 beta-hydroxysteroid dehydrogenase to human chromosome bands $10 \mathrm{p} 15 \rightarrow \mathrm{p} 14$ and mouse chromosome 13 region A2 by in situ hybridization: identification of a new syntenic relationship. Cytogenet Genome Res. 1999:84(3-4):241-2.

163. Pelletier G, Luu-The V, Tětu B, Labrie F. Immunocytochemical localization of type $517 \beta$-hydroxysteroid dehydrogenase in human reproductive tissues. J Histochem Cytochem. 1999:47(6):731-7.

164. Qin K, Ehrmann DA, Cox N, Refetoff S, Rosenfield RL. Identification of a functional polymorphism of the human type $517 \beta$-hydroxysteroid dehydrogenase gene associated with polycystic ovary syndrome. J Clin Endocrinol Metab. 2006:91(1):270-6

165. Ju R, Wu W, Fei J, Qin Y, Tang Q, Wu D, et al. Association analysis between the polymorphisms of HSD17B5 and HSD17B6 and risk of polycystic ovary syndrome in Chinese population. Eur J Endocrinol. 2015;172(3):227-33

166. Maier PS, Mattiello SS, Lages L, Spritzer PM. 17-hydroxysteroid dehydrogenase type 5 gene polymorphism (-71A/G HSD17B5 SNP) and treatment with oral contraceptive pills in PCOS women without metabolic comorbidities. Gynecol Endocrinol. 2012;28(8):606-10.

167. Cousin P, Billotte J, Chaubert P, Shaw P. Physical map of $17 \mathrm{p} 13$ and the genes adjacent to p53. Genomics. 2000;63(1):60-8.

168. Kahn S, Hryb D, Nakhla A, Romas N, Rosner W. Beyond carrier proteins: sex hormone-binding globulin is synthesized in target cells. J Endocrinol. 2002;175:113-20.

169. Hammond GL. Plasma steroid-binding proteins: primary gatekeepers of steroid hormone action. J Endocrinol. 2016;230(1):R13-25.

170. Rosner W, Hryb DJ, Kahn SM, Nakhla AM, Romas N. Interactions of sex hormone-binding globulin with target cells. Mol Cell Endocrinol. 2010;316(1):79-85.

171. Pugeat M, Crave JC, Tourniaire J, Forest MG. Clinical utility of sex hormone-binding globulin measurement. Horm Res Paediatr. 1996:45(3-5):148-55.

172. Davison SL, Bell R, Donath S, Montalto J, Davis SR. Androgen levels in adult females: changes with age, menopause, and oophorectomy. J Clin Endocrinol Metab. 2005;90(7):3847-53.

173. Burger HG, Dudley EC, Cui J, Dennerstein L, Hopper JL. A prospective longitudinal study of serum testosterone, dehydroepiandrosterone sulfate, and sex hormone-binding globulin levels through the menopause transition. J Clin Endocrinol Metab. 2000;85(8):2832-8. 
174. Pasquali R, Vicennati V, Bertazzo D, Casimirri F, Pascal G, Tortelli O, et al. Determinants of sex hormone-binding globulin blood concentrations in premenopausal and postmenopausal women with different estrogen status. Metabolism. 1997;46(1):5-9.

175. Rannevik G, Jeppsson S, Johnell OA, Bjerre B, Laurell-BorulfY, Svanberg $L$. A longitudinal study of the perimenopausal transition: altered profiles of steroid and pituitary hormones, SHBG and bone mineral density. Maturitas. 1995;21(2):103-13.

176. Ring HZ, Lessov CN, Reed T, Marcus R, Holloway L, Swan GE, et al. Heritability of plasma sex hormones and hormone binding globulin in adult male twins. J Clin Endocrinol Metab. 2005;90(6):3653-8.

177. Xita N, Tsatsoulis A. Genetic variants of sex hormone-binding globulin and their biological consequences. Mol Cell Endocrinol. 2010:316(1):60-5.

178. Hogeveen KN, Cousin P, Pugeat M, Dewailly D, Soudan B, Hammond GL. Human sex hormone-binding globulin variants associated with hyperandrogenism and ovarian dysfunction. J Clin Invest. 2002;109(7):973-81.

179. Xita N, Georgiou I, Lazaros L, Psofaki V, Kolios G, Tsatsoulis A. The synergistic effect of sex hormone-binding globulin and aromatase genes on polycystic ovary syndrome phenotype. Eur J Endocrinol. 2008;158(6):861-6.

180. Fan W, Li S, Chen Q, Huang Z. Association between the (TAAAA) n SHBG polymorphism and PCOS: a systematic review and meta-analysis. Gynecol Endocrinol. 2013;29(7):645-50.

181. Ding EL, Song Y, Manson JE, Hunter DJ, Lee CC, Rifai N, et al. Sex hormone-binding globulin and risk of type 2 diabetes in women and men. N Engl J Med. 2009;361(12):1152-63.

182. Perry JR, Weedon MN, Langenberg C, Jackson AU, Lyssenko V, Spars $\varnothing$ $\mathrm{T}$, et al. Genetic evidence that raised sex hormone binding globulin (SHBG) levels reduce the risk of type 2 diabetes. Hum Mol Genet. 2010;19(3):535-44.

183. Abu-Hijleh TM, Gammoh E, Al-Busaidi AS, Malalla ZH, Madan S, Mahmood N, et al. Common variants in the sex hormone-binding globulin (SHBG) gene influence SHBG levels in women with polycystic ovary syndrome. Ann Nutr Metab. 2016;68(1):66-74.

184. Chamberlain NL, Driver ED, Miesfeld RL. The length and location of CAG trinucleotide repeats in the androgen receptor $\mathrm{N}$-terminal domain affect transactivation function. Nucleic Acids Res. 1994;22(15):3181-6.

185. Azziz R, Carmina E, Dewailly D, Diamanti-Kandarakis E, Escobar-Morreale HF, Futterweit W, et al. The Androgen Excess and PCOS Society criteria for the polycystic ovary syndrome: the complete task force report. Fertil Steril. 2009;91(2):456-88.

186. Adams J, Polson D, Franks S. Prevalence of polycystic ovaries in women with anovulation and idiopathic hirsutism. Br Med J (Clin Res Ed). 1986;293(6543):355-9.

187. Xita N, Tsatsoulis A. Fetal programming of polycystic ovary syndrome by androgen excess: evidence from experimental, clinical, and genetic association studies. J Clin Endocrinol Metab. 2006:91(5):1660-6.

188. Walters K, Allan C, Handelsman D. Androgen actions and the ovary. Biol Reprod. 2008;78(3):380-9.

189. Schüring A, Welp A, Gromoll J, Zitzmann M, Sonntag B, Nieschlag E, et al. Role of the CAG repeat polymorphism of the androgen receptor gene in polycystic ovary syndrome (PCOS). Exp Clin Endocrinol Diabetes. 2012;120(2):73.

190. Rajender S, Carlus SJ, Bansal SK, Negi MPS, Sadasivam N, Sadasivam $M N$, et al. Androgen receptor CAG repeats length polymorphism and the risk of polycystic ovarian syndrome (PCOS). PLoS One. 2013;8(10):e75709.

191. Ferk P, Perme MP, Teran N, Gersak K. Androgen receptor gene (CAG) n polymorphism in patients with polycystic ovary syndrome. Fertil Steril. 2008;90(3):860-3.

192. Kim JJ, Choung SH, Choi YM, Yoon SH, Kim SH, Moon SY, et al. Androgen receptor gene CAG repeat polymorphism in women with polycystic ovary syndrome. Fertil Steril. 2008;90(6):2318-23.

193. Skrgatic L, Baldani DP, Cerne J, Ferk P, Gersak K. CAG repeat polymorphism in androgen receptor gene is not directly associated with polycystic ovary syndrome but influences serum testosterone levels. J Steroid Biochem Mol Biol. 2012;128(3-5):107-12.

194. Ramos Cirilo PD, Rosa FE, Moreira Ferraz MF, Rainho CA, Pontes A, Rogatto SR. Genetic polymorphisms associated with steroids metabolism and insulin action in polycystic ovary syndrome. Gynecol Endocrinol. 2012;28(3):190-4.

195. Peng CY, Xie HJ, Guo ZF, Nie YL, Chen J, Zhou JM, et al. The association between androgen receptor gene CAG polymorphism and polycystic ovary syndrome: a case-control study and meta-analysis. J Assist Reprod Genet. 2014;31(9):1211-9.

196. Hickey T, Chandy A, Norman RJ. The androgen receptor CAG repeat polymorphism and X-chromosome inactivation in Australian Caucasian women with infertility related to polycystic ovary syndrome. J Clin Endocrinol Metab. 2002;87(1):161-5.

197. Westberg L, Baghaei F, Rosmond R, Hellstrand M, Landén M, Jansson M, et al. Polymorphisms of the androgen receptor gene and the estrogen receptor $\beta$ gene are associated with androgen levels in women. J Clin Endocrinol Metab. 2001:86(6):2562-8.

198. Otsuka F, Yao Z, Lee T-H, Yamamoto S, Erickson GF, Shimasaki S. Bone morphogenetic protein-15: identification of target cells and biological functions. J Biol Chem. 2000;275(50):39523-8.

199. Otsuka F, Shimasaki S. A novel function of bone morphogenetic protein-15 in the pituitary: selective synthesis and secretion of FSH by gonadotropes. Endocrinology. 2002;143(12):4938-41.

200. Calvo RM, Asunción M, Sancho J, San Millán JL, Escobar-Morreale HF. The role of the CAG repeat polymorphism in the androgen receptor gene and of skewed $X$-chromosome inactivation, in the pathogenesis of hirsutism. J Clin Endocrinol Metab. 2000;85(4):1735-40.

201. Peng C, Long X, Lu G. Association of AR rs6152G/A gene polymorphism with susceptibility to polycystic ovary syndrome in Chinese women. Reprod Fertil Dev. 2010;22(5):881-5.

202. Zhang T, Liang W, Fang M, Yu J, Ni Y, Li Z. Association of the CAG repeat polymorphisms in androgen receptor gene with polycystic ovary syndrome: a systemic review and meta-analysis. Gene. 2013;524(2):161-7.

203. Wang R, Goodarzi MO, Xiong T, Wang D, Azziz R, Zhang H. Negative association between androgen receptor gene CAG repeat polymorphism and polycystic ovary syndrome? A systematic review and metaanalysis. Mol Hum Reprod. 2012;18(10):498-509.

204. Jehaimi CT, Araiza VC, Batish SD, Brosnan PG. Polycystic ovaries and adrenal insufficiency in a young pubescent female with lipoid congenital adrenal hyperplasia due to splice mutation of the StAR gene: a case report and review of the literature. J Pediatr Endocrinol Metab. 2010;23(12):1225-31.

205. Barbar É, LeHoux J-G, Lavigne P. Toward the NMR structure of StAR. Mol Cell Endocrinol. 2009;300(1-2):89-93.

206. Miller WL. Steroidogenic acute regulatory protein (StAR), a novel mitochondrial cholesterol transporter. Biochim Biophys Acta. 2007;1771(6):663-76.

207. Jakimiuk AJ, Weitsman SR, Navab A, Magoffin DA. Luteinizing hormone receptor, steroidogenesis acute regulatory protein, and steroidogenic enzyme messenger ribonucleic acids are overexpressed in thecal and granulosa cells from polycystic ovaries. J Clin Endocrinol Metab. 2001:86(3):1318-23

208. Kahsar-Miller MD, Conway-Myers BA, Boots LR, Azziz R. Steroidogenic acute regulatory protein (StAR) in the ovaries of healthy women and those with polycystic ovary syndrome. Am J Obstet Gynecol. 2001:185(6):1381-7.

209. Nazouri A-S, Khosravifar M, Akhlaghi A-A, Shiva M, Afsharian P. No relationship between most polymorphisms of steroidogenic acute regulatory (StAR) gene with polycystic ovarian syndrome. Int J Reprod Biomed. 2015;13(12):771.

210. Seino S, Seino M, Bell Gl. Human insulin-receptor gene. Diabetes. 1990;39(2):129-33.

211. Rager KM, Omar HA. Androgen excess disorders in women: the severe insulin-resistant hyperandrogenic syndrome, HAIR-AN. ScientificWorldJournal. 2006:6:116-21.

212. Diamanti-Kandarakis E, Papavassiliou AG. Molecular mechanisms of insulin resistance in polycystic ovary syndrome. Trends Mol Med. 2006;12(7):324-32.

213. Jin L, Zhu X-M, Luo Q, Qian Y, Jin F, Huang H-F. A novel SNP at exon 17 of INSR is associated with decreased insulin sensitivity in Chinese women with PCOS. Mol Hum Reprod. 2006;12(3):151-5.

214. Tucci S, Futterweit W, Concepcion ES, Greenberg DA, Villanueva R, Davies TF, et al. Evidence for association of polycystic ovary syndrome 
in caucasian women with a marker at the insulin receptor gene locus. J Clin Endocrinol Metab. 2001;86(1):446-9.

215. Goodarzi MO, Louwers YV, Taylor KD, Jones MR, Cui J, Kwon S, et al. Replication of association of a novel insulin receptor gene polymorphism with polycystic ovary syndrome. Fertil Steril. 2011;95(5):1736-41.e11.

216. Hanzu FA, Radian S, Attaoua R, Ait-El-Mkadem S, Fica S, Gheorghiu M, et al. Association of insulin receptor genetic variants with polycystic ovary syndrome in a population of women from Central Europe. Fertil Steril. 2010;94(6):2389-92.

217. Feng C, Lv P-P, Yu T-T, Jin M, Shen J-M, Wang X, et al. The association between polymorphism of INSR and polycystic ovary syndrome: a meta-analysis. Int J Mol Sci. 2015;16(2):2403-25.

218. Rousseau-Merck M, Atger M, Loosfelt H, Milgrom E, Berger R. The chromosomal localization of the human follicle-stimulating hormone receptor gene (FSHR) on 2p21-p16 is similar to that of the luteinizing hormone receptor gene. Genomics. 1993;15(1):222-4.

219. Dufau ML. The luteinizing hormone receptor. Annu Rev Physiol. 1998;60(1):461-96.

220. Latronico AC, Lins TSS, Brito VN, Arnhold IJP, Mendonca BB. The effect of distinct activating mutations of the luteinizing hormone receptor gene on the pituitary-gonadal axis in both sexes. Clin Endocrinol. 2000;53(5):609-13.

221. Mutharasan P, Galdones E, Peñalver Bernabé B, Garcia OA, Jafari N, Shea $L D$, et al. Evidence for chromosome 2p16. 3 polycystic ovary syndrome susceptibility locus in affected women of European ancestry. J Clin Endocrinol Metab. 2013;98(1):E185-E90.

222. Goodarzi MO, Jones MR, Li X, Chua AK, Garcia OA, Chen Y-DI, et al. Replication of association of DENND1A and THADA variants with polycystic ovary syndrome in European cohorts. J Med Genet. 2012;49(2):90-5.

223. Eriksen MB, Brusgaard K, Andersen M, Tan Q, Altinok ML, Gaster M, et al. Association of polycystic ovary syndrome susceptibility single nucleotide polymorphism rs2479106 and PCOS in Caucasian patients with PCOS or hirsutism as referral diagnosis. Eur J Obstet Gynecol Reprod Biol. 2012;163(1):39-42.

224. Welt CK, Styrkarsdottir U, Ehrmann DA, Thorleifsson G, Arason G, Gudmundsson JA, et al. Variants in DENND 1A are associated with polycystic ovary syndrome in women of European ancestry. J Clin Endocrinol Metab. 2012;97(7):E1342-E7.

225. Gromoll J, Ried T, Holtgreve-Grez H, Nieschlag E, Gudermann T. Localization of the human FSH receptor to chromosome 2 p21 using a genomic probe comprising exon 10. J Mol Endocrinol. 1994;12(3):265-71.

226. Gromoll J, Simoni M. Genetic complexity of FSH receptor function. Trends Endocrinol Metab. 2005;16(8):368-73.

227. Huhtaniemi I. The Parkes lecture. Mutations of gonadotrophin and gonadotrophin receptor genes: what do they teach us about reproductive physiology? Reproduction. 2000;119(2):173-86.

228. Qiu L, Liu J, Hei Q-M. Association between two polymorphisms of follicle stimulating hormone receptor gene and susceptibility to polycystic ovary syndrome: a meta-analysis. Chin Med Sci J. 2015;30(1):44-50.

229. Louwers YV, Stolk L, Uitterlinden AG, Laven JS. Cross-ethnic meta-analysis of genetic variants for polycystic ovary syndrome. J Clin Endocrinol Metab. 2013:98(12):E2006-E12.

230. Naor Z. Signaling by G-protein-coupled receptor (GPCR): studies on the GnRH receptor. Front Neuroendocrinol. 2009;30(1):10-29.

231. Aguilar-Rojas A, Huerta-Reyes M. Human gonadotropin-releasing hormone receptor-activated cellular functions and signaling pathways in extra-pituitary tissues and cancer cells. Oncol Rep. 2009;22(5):981-90.

232. Ciccone NA, Kaiser UB. The biology of gonadotroph regulation. Curr Opin Endocrinol Diabetes Obes. 2009;16(4):321.

233. Chen W-Y, Du Y-Q, Guan X, Zhang H-Y, Liu T. Effect of GnRHR polymorphisms on in vitro fertilization and embryo transfer in patients with polycystic ovary syndrome. J Hum Genet. 2017;62(12):1065-71.

234. Dinarello CA. Interleukin-1, interleukin-1 receptors and interleukin-1 receptor antagonist. Int Rev Immunol. 1998;16(5-6):457-99.

235. Nicklin MJ, Weith A, Duff GW. A physical map of the region encompassing the human interleukin-1 $\alpha$, interleukin-1 $\beta$, and interleukin-1 receptor antagonist genes. Genomics. 1994;19(2):382-4.

236. Sukhikh GT, Vanko LV. Interrelationships between immune and reproductive systems in human. Russ J Immunol. 1999;4(4):312-4.
237. Beamer BA, Negri C, Yen C-J, Gavrilova O, Rumberger JM, Durcan MJ, et al. Chromosomal localization and partial genomic structure of the human peroxisome proliferator activated receptor-gamma (hPPARY) gene. Biochem Biophys Res Commun. 1997;233(3):756-9.

238. Antoine HJ, Pall M, Trader BC, Chen Y-DI, Azziz R, Goodarzi MO, et al. Genetic variants in peroxisome proliferator-activated receptor gamma influence insulin resistance and testosterone levels in normal women, but not those with polycystic ovary syndrome. Fertil Steril. 2007:87(4):862-9.

239. Zaki M, Hassan N, El-Bassyouni HT, Kamal S, Basha W, Azmy O, et al. Association of the Pro12Ala polymorphism with the metabolic parameters in women with polycystic ovary syndrome. Open Access Maced J Med Sci. 2017:5(3):275.

240. Orio F Jr, Matarese G, Di Biase S, Palomba S, Labella D, Sanna V, et al. Exon 6 and 2 peroxisome proliferator-activated receptor- $y$ polymorphisms in polycystic ovary syndrome. J Clin Endocrinol Metab. 2003;88(12):5887-92.

241. Orio F Jr, Palomba S, Cascella T, Di Biase S, Labella D, Russo T, et al. Lack of an association between peroxisome proliferator-activated receptor- $\gamma$ gene Pro12Ala polymorphism and adiponectin levels in the polycystic ovary syndrome. J Clin Endocrinol Metab. 2004;89(10):5110-5.

242. Haap M, Machicao F, Stefan N, Thamer C, Tschritter O, Schnuck F, et al. Genetic determinants of insulin action in polycystic ovary syndrome. Exp Clin Endocrinol Diabetes. 2005;113(05):275-81.

243. Xita N, Lazaros L, Georgiou I, Tsatsoulis A. The Pro12Ala polymorphism of the PPAR- $\gamma$ gene is not associated with the polycystic ovary syndrome. Hormones. 2009;8(4):267-72.

244. West A, Vojta PJ, Welch DR, Weissman BE. Chromosome localization and genomic structure of the KiSS-1 metastasis suppressor gene (KISS1). Genomics. 1998;54(1):145-8.

245. Lee J-H, Miele ME, Hicks DJ, Phillips KK, Trent JM, Weissman BE, et al. KiSS-1, a novel human malignant melanoma metastasis-suppressor gene. J Natl Cancer Inst. 1996;88(23):1731-7.

246. De Roux N, Genin E, Carel J-C, Matsuda F, Chaussain J-L, Milgrom E. Hypogonadotropic hypogonadism due to loss of function of the KiSS1-derived peptide receptor GPR54. Proc Natl Acad Sci. 2003;100(19):10972-6.

247. Oride A, Kanasaki H, Mijiddorj T, Sukhbaatar U, Ishihara T, Kyo S, et al. Regulation of kisspeptin and gonadotropin-releasing hormone expression in rat placenta: study using primary cultures of rat placental cells. Reprod Biol Endocrinol. 2015;13(1):1-9.

248. Xie C, Jonak CR, Kauffman AS, Coss D. Gonadotropin and kisspeptin gene expression, but not $\mathrm{GnRH}$, are impaired in cFOS deficient mice. Mol Cell Endocrinol. 2015;411:223-31.

249. Dhillo WS, Chaudhri OB, Patterson M, Thompson EL, Murphy KG, Badman MK, et al. Kisspeptin-54 stimulates the hypothalamicpituitary gonadal axis in human males. J Clin Endocrinol Metab. 2005;90:6609-15.

250. Messager S, Chatzidaki EE, Ma D, Hendrick AG, Zahn D, Dixon J. Kisspeptin directly stimulates gonadotropin-releasing hormone release via $G$ protein-coupled receptor. PNAS. 2005;54:1761-6.

251. Jayasena CN, Abbara A, Veldhuis JD, Comninos AN, Ratnasabapathy R, De Silva A, et al. Increasing LH pulsatility in women with hypothalamic amenorrhoea using intravenous infusion of Kisspeptin-54. J Clin Endocrinol Metab. 2014;99(6):E953-E61.

252. Han S-K, Gottsch ML, Lee KJ, Popa SM, Smith JT, Jakawich SK, et al. Activation of gonadotropin-releasing hormone neurons by kisspeptin as a neuroendocrine switch for the onset of puberty. J Neurosci. 2005;25(49):11349-56.

253. Zhang C, Roepke TA, Kelly MJ, Rønnekleiv OK. Kisspeptin depolarizes gonadotropin-releasing hormone neurons through activation of TRPClike cationic channels. J Neurosci. 2008;28(17):4423-34.

254. Novaira HJ, Ng Y, Wolfe A, Radovick S. Kisspeptin increases GnRH mRNA expression and secretion in GnRH secreting neuronal cell lines. Mol Cell Endocrinol. 2009;311(1-2):126-34.

255. Oakley AE, Clifton DK, Steiner RA. Kisspeptin signaling in the brain. Endocr Rev. 2009;30(6):713-43.

256. Chen X, Mo Y, Li L, Chen Y, Li Y, Yang D, et al. Increased plasma metastin levels in adolescent women with polycystic ovary syndrome. Eur J Obstet Gynecol Reprod Biol. 2010;149(1):72-6. 
257. Katulski K, Podfigurna A, Czyzyk A, Meczekalski B, Genazzani AD. Kisspeptin and LH pulsatile temporal coupling in PCOS patients. Endocrine. 2018;61(1):149-57.

258. Gorkem U, Togrul C, Arslan E, Sargin Oruc A, Buyukkayaci Duman N. Is there a role for kisspeptin in pathogenesis of polycystic ovary syndrome? Gynecol Endocrinol. 2018;34(2):157-60.

259. Panidis D, Rousso D, Koliakos G, Kourtis A, Katsikis I, Farmakiotis D, et al. Plasma metastin levels are negatively correlated with insulin resistance and free androgens in women with polycystic ovary syndrome. Fertil Steril. 2006;85(6):1778-83.

260. Albalawi FS, Daghestani MH, Daghestani MH, Eldali A, Warsy AS. rs4889 polymorphism in KISS1 gene, its effect on polycystic ovary syndrome development and anthropometric and hormonal parameters in Saudi women. J Biomed Sci. 2018;25(1):50.

261. Taymans SE, Pack S, Pak E, Orban Z, Barsony J, Zhuang Z, et al. The human vitamin D receptor gene (VDR) is localized to region 12cen-q12 by fluorescent in situ hybridization and radiation hybrid mapping: genetic and physical VDR map. J Bone Miner Res. 1999;14(7):1163-6.

262. Colonese F, Laganà AS, Colonese E, Sofo V, Salmeri FM, Granese R, et al. The pleiotropic effects of vitamin D in gynaecological and obstetric diseases: an overview on a hot topic. Biomed Res Int. 2015;2015:986281.

263. Agic A, Xu H, Altgassen C, Noack F, Wolfler MM, Diedrich K, et al. Relative expression of 1, 25-dihydroxyvitamin D3 receptor, vitamin D 1a-hydroxylase, vitamin D 24-hydroxylase, and vitamin D 25-hydroxylase in endometriosis and gynecologic cancers. Reprod Sci. 2007;14(5):486-97.

264. Lerchbaum E, Obermayer-Pietsch B. Vitamin D and fertility: a systematic review. Eur J Endocrinol. 2012;166(5):765-78.

265. Parikh G, Varadinova M, Suwandhi P, Araki T, Rosenwaks Z, Poretsky L, et al. Vitamin D regulates steroidogenesis and insulin-like growth factor binding protein-1 (IGFBP-1) production in human ovarian cells. Horm Metab Res. 2010;42(10):754-7.

266. Pittas AG, Lau J, Hu FB, Dawson-Hughes B. The role of vitamin D and calcium in type 2 diabetes. A systematic review and meta-analysis. J Clin Endocrinol Metab. 2007:92(6):2017-29.

267. Ngo DTM, Chan W, Rajendran S, Heresztyn T, Amarasekera A, Sverdlov $A L$, et al. Determinants of insulin responsiveness in young women: impact of polycystic ovarian syndrome, nitric oxide, and vitamin D. Nitric Oxide. 2011;25(3):326-30.

268. Mahmoudi T, Majidzadeh-A K, Farahani H, Mirakhorli M, Dabiri R, Nobakht $H$, et al. Association of vitamin D receptor gene variants with polycystic ovary syndrome: a case control study. Int J Reprod Biomed. 2015;13(12):793.

269. Frayling TM, Timpson NJ, Weedon MN, Zeggini E, Freathy RM, Lindgren $\mathrm{CM}$, et al. A common variant in the FTO gene is associated with body mass index and predisposes to childhood and adult obesity. Science (New York, NY). 2007;316(5826):889-94.

270. Hubacek JA, Staněk V, Gebauerová M, Pilipčincová A, Dlouhá D, Poledne $\mathrm{R}$, et al. A FTO variant and risk of acute coronary syndrome. Clin Chim Acta. 2010;411(15-16):1069-72.

271. Larder R, Cheung MM, Tung YL, Yeo GS, Coll AP. Where to go with FTO? Trends Endocrinol Metab. 2011;22(2):53-9.

272. Shi Y, Guo M, Yan J, Sun W, Zhang X, Geng L, et al. Analysis of clinical characteristics in large-scale Chinese women with polycystic ovary syndrome. Neuroendocrinol Lett. 2007;28(6):807-10.

273. Kim JJ, Choi YM, Hong MA, Kim JM, Hwang SS, Lee GH, et al. Gene dose effect between a fat mass and obesity-associated polymorphism and body mass index was observed in Korean women with polycystic ovary syndrome but not in control women. Fertil Steril. 2014;102(4):1143-8. e2.

274. Saxena R, Welt C. Polycystic ovary syndrome is not associated with genetic variants that mark risk of type 2 diabetes. Acta Diabetol. 2013;50(3):451-7.
275. Ewens KG, Jones MR, Ankener W, Stewart DR, Urbanek M, Dunaif A, et al. FTO and MC4R gene variants are associated with obesity in polycystic ovary syndrome. PLoS One. 2011;6(1):e16390.

276. Bastien J, Rochette-Egly C. Nuclear retinoid receptors and the transcription of retinoid-target genes. Gene. 2004;328:1-16.

277. Clagett-Dame M, DeLuca HF. The role of vitamin A in mammalian reproduction and embryonic development. Annu Rev Nutr. 2002;22(1):347-81.

278. Bagavandoss P, Midgley A Jr. Lack of difference between retinoic acid and retinol in stimulating progesterone production by luteinizing granulosa cells in vitro. Endocrinology. 1987;121(1):420-8.

279. Lee H-K, Yoo M-S, Choi H-S, Kwon H-B, Soh J. Retinoic acids up-regulate steroidogenic acute regulatory protein gene. Mol Cell Endocrinol. 1999;148(1-2):1-10.

280. Wickenheisser JK, Nelson-DeGrave VL, Hendricks KL, Legro RS, Strauss JF III, McAllister JM, et al. Retinoids and retinol differentially regulate steroid biosynthesis in ovarian theca cells isolated from normal cycling women and women with polycystic ovary syndrome. J Clin Endocrinol Metab. 2005;90(8):4858-65.

281. Wood JR, Nelson VL, Ho C, Jansen E, Wang CY, Urbanek M, et al. The molecular phenotype of polycystic ovary syndrome (PCOS) theca cells and new candidate PCOS genes defined by microarray analysis. J Biol Chem. 2003;278(29):26380-90.

282. Ishihara Y, Sakurai H, Oguro A, Tsuji M, Vogel CF, Yamazaki T, et al. Retinoid $X$ receptor-mediated neuroprotection via CYP19 upregulation and subsequent increases in estradiol synthesis. J Steroid Biochem Mol Biol. 2019;193:105421.

283. Tal R, Seifer DB, Arici A. The emerging role of angiogenic factor dysregulation in the pathogenesis of polycystic ovarian syndrome. Semin Reprod Med. 2015;33(3):195-207.

284. Giovanni Artini P, Monteleone P, Parisen Toldin MR, Matteucci C, Ruggiero M, Cela V, et al. Growth factors and folliculogenesis in polycystic ovary patients. Expert Rev Endocrinol Metab. 2007;2(2):215-23.

285. Peitsidis P, Agrawal R. Role of vascular endothelial growth factor in women with PCO and PCOS: a systematic review. Reprod BioMed Online. 2010;20(4):444-52.

286. Daghestani MH, Daghestani MH, Warsy A, El-Ansary A, Omair MA, Omair $M A$, et al. Adverse effects of selected markers on the metabolic and endocrine profiles of obese women with and without PCOS. Front Endocrinol. 2021:12:665446.

287. van Sande ME, Scharpé SL, Neels HM, Van Camp KO. Distribution of angiotensin converting enzyme in human tissues. Clin Chim Acta. 1985;147(3):255-60

288. Rigat B, Hubert C, Alhenc-Gelas F, Cambien F, Corvol P, Soubrier F. An insertion/deletion polymorphism in the angiotensin I-converting enzyme gene accounting for half the variance of serum enzyme levels. J Clin Invest. 1990;86(4):1343-6.

289. Jia H, Wang B, Yu L, Jiang Z. Association of angiotensin-converting enzyme gene insertion/deletion polymorphism with polycystic ovary syndrome: a meta-analysis. J Renin-Angiotensin-Aldosterone Syst. 2013;14(3):255-62.

290. Alphan Z, Berberoglu Z, Gorar S, Candan Z, Aktas A, Aral Y, et al. Increased total renin levels but not angiotensin-converting enzyme activity in obese patients with polycystic ovary syndrome. Med Princ Pract. 2013;22(5):475-9.

\section{Publisher's Note}

Springer Nature remains neutral with regard to jurisdictional claims in published maps and institutional affiliations. 